This is a self-archived - parallel published version of this article in the publication archive of the University of Vaasa. It might differ from the original.

\title{
Financial development, government bond returns, and stability: International evidence
}

Author(s): Boubaker, Sabri; Nguyen, Duc Khuong; Piljak, Vanja; Savvides, Andreas

Title: $\quad$ Financial development, government bond returns, and stability: International evidence

Year: $\quad 2019$

Version: Accepted manuscript

Copyright (C) 2019 Elsevier. This manuscript version is made available under the Creative Commons Attribution-NonCommercial-NoDerivatives 4.0 International (CC BY-NC-ND 4.0) license, https://creativecommons.org/licenses/by-nc-nd/4.o/

\section{Please cite the original version:}

Boubaker, S., Nguyen, D. K., Piljak, V. \& Savvides, A. (2019). Financial development, government bond returns, and stability: International evidence. Journal of International Financial Markets, Institutions and Money 61, 81-96. https://doi.org/10.1016/j.intfin.2019.02.006 


\title{
Financial Development, Government Bond Returns, and Stability: International Evidence
}

\author{
Sabri Boubaker ${ }^{\mathrm{a}}$, Duc Khuong Nguyen ${ }^{\mathrm{b}}$, Vanja Piljak ${ }^{\mathrm{c}, *}$, Andreas Savvides $^{\mathrm{d}}$ \\ ${ }^{a}$ South Champagne Business School, France \\ b IPAG Business School, Paris, France \\ ${ }^{\mathrm{c}}$ University of Vaasa, School of Accounting and Finance, Vaasa, Finland \\ d Cyprus University of Technology, Limassol, Cyprus
}

Published in Journal of International Financial Markets, Institutions, and Money, (2019), Volume 61, pp. 81-96

\begin{abstract}
This paper investigates the effect of financial development on government bond returns in developed and emerging markets under different market conditions. Using a quantile regression framework for quarterly panel data from 28 countries over 1999-2015, our results reveal that the effect of financial development on government bond returns (changes in bond prices) differs according to conditions in the market and between developed and emerging markets. The effect is positive and significant only in good market conditions for developed markets. For emerging markets financial development has a positive and significant effect for good market conditions but the effect is negative and significant for bad market conditions.
\end{abstract}

JEL classification: F30; G15

Keywords: Financial development; Government bond markets; Emerging markets; Quantile regression

\footnotetext{
* Corresponding author: School of Accounting and Finance, University of Vaasa. P.O. Box 700, FI-65101 Vaasa, Finland.

E-mail addresses: sabri.boubaker@get-mail.fr (S. Boubaker), duc.nguyen@ipag.fr (D.K. Nguyen), vanja.piljak@uva.fi (V.Piljak), andreas.savvides@cut.ac.cy (A. Savvides)

Funding: This work was supported by the Evald and Hilda Nissi Foundation, Finland; and the Waldemar von Frenckells Foundation, Finland.
} 


\section{Introduction}

The purpose of this paper is twofold. First, it examines the effect of financial development on government bond returns in both developed and emerging economies. Second, it investigates whether this effect differs under different market conditions through a quantile regression framework. Previous studies have mainly focused on examining how financial development is related to economic growth (Beck et al., 2000; Beck and Levine, 2004), stock market returns (Dellas and Hess, 2005), financial liberalization (Chinn and Ito, 2006), and monetary policy effectiveness (Ma and Lin, 2016). These studies provide strong evidence that financial development is linked to stock market returns and economic growth. There is, however, very limited empirical evidence concerning the effects of financial development on government bond returns.

The relationship between financial development and government bond markets has been partly and indirectly addressed in the following contexts: i) the role of stock and bond market development in determining government bond yields (Huang et al., 2015); ii) the link between the sovereign default and financial development (Gennaioli et al., 2014); and iii) the impact of financial development on the size and currency composition of government bond markets (Claessens et al., 2007). In particular, Claessens et al. (2007) find that countries with more developed financial systems, as represented by bank deposit volume and stock market capitalization, have larger domestic currency bond markets and issue less foreign currency debt. They also document a positive effect of foreign investor demand on the size and share of foreign currency bonds. Huang et al. (2015) show that government bond yields are negatively associated with stock and bond market development. Gennaioli et al. (2014) argue that government defaults lead to declines in private credit and countries with more developed financial institutions experience larger declines in private credit. Their main conclusion is that the willingness of a government to repay its debts depends on the development of domestic financial institutions. 
Our study also examines the relationship between financial development and government bond returns, but from an investor's perspective. Our motivation comes from the observation that the development of the financial system directly affects asset returns through the main function of the financial system to channel credit and indirectly through its effects on economic growth. ${ }^{1}$ Thus, we focus on explaining the interlinkage between financial development, economic growth, and government bond markets. Previous literature investigating the relationship between financial markets and economic growth mainly focuses on the role of stock markets and banks in explaining economic growth (e.g. Levine and Zervos, 1998; Rousseau and Wachtel, 2000; Beck and Levine, 2004) and suggests a positive effect of financial development on economic growth.

The role of bond markets in explaining economic growth has received much less attention than the role of stock markets and banks. This followed from the notion that a country's overall financial development is relevant, but the difference in the composition (e.g. stock markets, banks, and bond markets) of a country's financial system is of less importance as long as the financial system is functioning well (see, Levine, 1997). However, recent studies suggest bond markets as a third pillar (in addition to banks and stock markets) of the financial system that is positively related to economic growth. In particular, Thumrongvit et al. (2013) provide empirical evidence about the positive effect of government bond markets on economic growth by using a panel of 38 developed and developing countries. Similarly, Pradhan et al. (2016) find a positive relationship between bond markets and economic growth by using sample of 35 countries, while Fink et al. (2003) show that development of bond markets significantly affects real economic activity in leading world economies (the USA, most of the European Union members, Japan, Switzerland and Norway). Those findings support the argument that bond market development increases the liquidity and size of the capital markets, and thus it is important for growth (see Wachtel, 2001).

\footnotetext{
${ }^{1}$ See, Beck et al. (2014) and Dellas and Hess (2005), for a more detailed discussion on the main functions of the financial system and their relation to asset returns.
} 
More recently, several studies have provided evidence that nonlinearities may characterize the linkage between financial development and economic growth. In particular, Shen and Lee (2006) suggest that this relationship has an inverse U-shape, while Masten et al. (2008) argue that the positive effect of the financial development on growth is higher in less developed countries. Arcand et al. (2012) document the existence of a threshold (100\% for the ratio of private credit to GDP) above which financial development has no longer a positive effect on economic growth. Beck et al. (2014) provide evidence that nonlinearity in the finance and growth nexus remains even after controlling for a number of structural features of a country's financial system. Henderson et al. (2013) also find nonlinearity in the association of financial development and growth, but the relationship is positive and stronger across time only for countries that belong to middle- and high-income group. In contrast, for low-income countries the level of financial development has a minor (or non-existent) role in determining growth.

The nonlinearities literature points to a non-uniform effect of financial development on growth. This is the driving motivation behind the adoption of the quantile regression (QR) approach in this paper that allows the impact of financial development on bond returns to differ depending on bond market conditions. The main advantage of the QR approach over classical regression is that the QR describes the entire conditional distribution of the dependent variable (bond returns), while the classical model describes only the conditional mean. ${ }^{2}$ Each of the different quantiles can be interpreted as a different state of the government bond returns. In particular, the highest quantile (95\%) represents the highest bond returns and is consistent with a good state of the bond market when returns are the highest ${ }^{3}$; the lowest quantile $(5 \%)$ represents the lowest bond re-

\footnotetext{
2 Since its introduction by Koenker and Bassett (1978), the QR approach has become a popular method in many areas of finance research such as (i) financial market stability (e.g. Baur and Schulze, 2009); (ii) financial dependence and contagion (e.g. Baur, 2013); and (iii) credit default swap spreads (e.g. Pires et al., 2015). A more detailed review of the application of QR can be found in Koenker and Hallock (2001).

${ }^{3}$ Bond returns in this paper refers to changes in bond prices not bond yields.
} 
turns consistent with a bad state, while the median quantile is consistent with a normal state. The QR approach allows us to empirically examine conditional dependence of specific quantiles of government bond returns on the level of financial development (conditioning variable), and thus provides information about a potentially asymmetric impact of financial development in different bond market conditions (good, bad, and normal). This econometric feature of QR offers an important advantage over classical regression because it enables a comparison between the effects of financial development over all quantiles and also gives insight into the stability of government bond markets. If the coefficients are stable over all quantiles, then the impact of financial development on government bond returns is the same regardless of market state. By contrast, if the coefficients in high or low quantiles are different from the median, then the impact differs with respect to the state of the bond market. The possible non-uniform effect of financial development on bond returns could arise from the indirect effect through economic growth. The argument for a potentially asymmetric impact can be linked to the findings of the previous literature. For instance, even though the early literature reported that financial development is positively linked to growth, a rapid increase in private credit is considered as an early-warning signal of a financial crisis (Demirgüç-Kunt and Detragiache, 2005; Jorda et al., 2011). Excessive growth in private credit may be a precursor to financial instability and, therefore, may have negative effects on bond prices. ${ }^{4}$ In addition, the potential of asymmetric impact can be connected to aforementioned evidence of nonlinearities in relationship between financial development and economic growth. Even though the main focus of our study is financial development, we also analyze the degree to which other country-specific and global factors affect government bond returns.

Our paper makes three main contributions to prior research. First, it complements the literature on the link between financial development and government bond markets (Claessens et al.,

\footnotetext{
${ }^{4}$ A recent study by Dawood et al. (2017) shows that domestic credit and bank asset growth have a substantial effect on the likelihood of a debt crisis.
} 
2007; Gennaioli et al., 2014; Huang et al., 2015) and extends this line of research by devoting special attention on how this link is related to differences in market conditions. Second, our paper builds upon the findings of Rioja and Valev (2004) and Henderson et al. (2013) that the stage of a country's development is important in how financial development affects economic growth. In this light, our empirical framework analyzes developed and emerging bond markets separately, and thus, we are able to make inferences about the factors that are relevant to government bond returns for these two groups of bond markets. It is well known that financial systems are more diversified and more mature in developed markets and investors treat financial instruments in these two groups of countries as distinct asset classes. Moreover, by treating them separately, we are able to reduce sample heterogeneity. Third, our paper complements research on the determinants of government bond pricing by investigating how a variety of economic, financial, and political factors, classified into broad categories that encompass global and country-specific factors, might affect government bond returns in emerging and developed markets. ${ }^{5}$ Our paper adds to this literature by showing that there is considerable variation in the role of specific local and global factors between emerging and developed bond markets. The most influential factors for developed markets are global bond market returns and global financial conditions, while the most prominent factor for emerging markets is sovereign credit rating. These factors are relevant in determining government bond returns regardless of bond market conditions (i.e., good or bad).

The paper is organized as follows. Section 2 discusses the related literature. Section 3 presents the data. Section 4 describes the quantile regression approach and our estimation strategy. Section 5 reports the estimation results and Section 6 concludes.

\footnotetext{
${ }^{5}$ The literature on the determinants of government bond pricing is discussed in the following section.
} 


\section{A brief review of related literature}

Our paper is linked to two major strands of the literature, namely, (i) the determinants of government bond pricing and (ii) the financial development-economic growth nexus, insofar as the latter is a major factor driving government bond yields.

The empirical literature on government bond pricing and bond yields is large. One common theme of the contributions is the distinction between domestic (local) and global (foreign) factors. For instance, Gómez-Puig (2009 a, b) finds that domestic factors, such as differences in market liquidity and in credit risk, are more important than international factors in explaining the evolution of 10-year yield spread in all EMU countries; however, in non-EMU countries international risk factors are more influential. Many studies provide evidence that global factors are important drivers of sovereign bond yields (e.g., Longstaff et al., 2011; Martell, 2008). In particular, Jaramillo and Weber (2013) emphasize the role of global risk aversion in determining bond yields in emerging economies. They find that bond yields are mainly affected by real GDP growth expectations and inflation during periods of low global risk aversion, while during periods of high risk aversion the role of country-specific fiscal fundamentals is more pronounced. Similarly, Kennedy and Palerm (2014) examine the role of global and local factors in determining emerging markets bond spreads and their results are in line with Jaramillo and Weber (2013) regarding the importance of global risk aversion. Jüttner et al. (2006) show that government bond returns in emerging markets may be explained by a bond pricing model that combines global factors with local country-specific risk factors (macroeconomic, political, and financial conditions factors). Dailami et al. (2008) examine the role of global monetary conditions and country-specific factors in explaining emerging market debt spreads. They find that the country-specific variables have greater influence on emerging markets spreads than US interest rates. Csonto et al. (2014) find evidence of increasing 
importance of global financial conditions in determining emerging market sovereign bond spreads during high volatility periods. ${ }^{6}$

Our research is also connected to the large body of the literature on the financial development-economic growth nexus. This literature is extensive and encompasses many different aspects (Durusu-Ciftci et al., 2017). ${ }^{7}$ One aspect is related to bond pricing, financial stability, and nonlinearities in the relationship between financial development and economic growth (this aspect is discussed in Introduction section). Another important aspect of this nexus relates to financial integration. There are important synergies between international financial integration and domestic financial development. According to Alfaro et al. (2004) and Kose et al. (2009), financial integration facilitates financial development, and, conversely, a well-developed financial system is a requirement for benefits from financial integration. Thus, in a more financially developed economy that is also more globally integrated, global factors should play a more important role in government bond pricing. Finally, the stage of a country's development influences how financial development affects economic growth, as shown by Rioja and Valev (2004). They show that the effect in lowincome countries is uncertain, while in middle- and high-income countries the effect is large and positive.

\section{Data}

Our quarterly panel data set contains the following variables: (i) government bond prices; (ii) domestic financial development; and (iii) a set of local (country-specific) and global factors that might affect government bond returns. The data covers the period from Q2:1999 to Q1:2015 and

\footnotetext{
${ }^{6}$ See, Csonto and Ivaschenko (2013) for a literature review on the links between emerging markets sovereign spreads and global/country-specific factors and Afonso and Jalles (2019) for a discussion on determinants of government bond yields.

${ }^{7}$ We limit our discussion to the research question addressed in this paper. See, Levine (2005), for a comprehensive overview of the financial development-economic growth nexus.
} 
the starting point and country selection are determined by data availability. The sample includes 28 countries, divided into two subsets: developed (18) and emerging economies (10 countries). The following sections provide a brief description of the variables and data sources.

\subsection{Government bond returns}

Our dependent variable is the total government bond return measured by the J.P. Morgan Emerging Markets Bond Index Global (EMBI Global) total return indices (with coupons reinvested) for emerging markets, and 10-year government bond total return indices for developed markets, sourced from Datastream International. Our dependent variable, government bond return, is the logarithmic first difference of the bond price index. ${ }^{8}$ The price indexes are quarterly and measured in terms of US dollars. Our sample includes 18 developed markets (Australia, Austria, Belgium, Canada, Denmark, Finland, France, Germany, Italy, Japan, Netherlands, Norway, Portugal, Spain, Sweden, Switzerland, the United Kingdom, and the United States), and 10 emerging markets (Argentina, Brazil, China, Hungary, Mexico, Malaysia, Poland, Russia, Turkey, and South Africa).

\subsection{Domestic financial development}

We measure domestic financial development as the ratio of credit to the private non-financial sector to Gross Domestic Product (GDP). Data for this variable is from the Bank for International Settlement (BIS) database. The BIS has constructed quarterly time-series data on credit to the private non-financial sector for 40 countries. According to the BIS, "private non-financial sector" includes non-financial private-owned and public-owned corporations, households and non-profit institutions serving households. "Credit" refers to credit provided by domestic banks, all other economic sectors and non-residents, and also includes loans and debt securities. We use the BIS's private credit-to-GDP ratio as our measure of financial development because it combines both the financial depth and the quality of financial service dimensions of financial development. It also repre-

\footnotetext{
${ }^{8}$ This measure has also been used by Kim et al. (2006), Christiansen (2007), and Piljak and Swinkels (2017).
} 
sents improvement over other measures that focus on either financial depth or quality of financial services (e.g., Levine et al., 2000, Beck et al., 2003, for more details on measuring financial development). ${ }^{9}$

\subsection{Local and global factors}

Our set of explanatory variables includes a number of local and global variables that may also affect government bond returns. The set of local factors includes the following variables:

i) Macroeconomic fundamentals represented by GDP growth and domestic inflation. ${ }^{10}$ Inflation is measured by the quarterly percentage change of the Consumer Price Index. Data are from the International Finance Statistics (IFS).

ii) Sovereign credit rating: We hypothesize that sovereign credit ratings influence government bond prices. An improvement in credit rating is expected to boost government bond prices (and lower government bond yields). ${ }^{11} \mathrm{We}$ measure sovereign credit rating by the Standard and Poor's (S\&P) rating at the end of each quarter. Although the S\&P provides sovereign ratings both in foreign and local currency, we use the foreign currency ratings (and longterm obligations) because it is a more relevant indicator of creditworthiness for international investors in government bonds. We transform letter designations of a country's credit rating into numerical terms that represents the country's Comprehensive Credit Rating (CCR). ${ }^{12}$ CCR is calculated by assigning to each letter rating provided by the S\&P (the letter ratings range from $\mathrm{AAA}$ to $\mathrm{SD} / \mathrm{D})$ a number from 21 to 0 so that higher numbers imply higher ratings.

\footnotetext{
${ }^{9}$ Prior studies often use private credit/GDP data provided by the World Bank's World Development Indicators and Global Financial Development Database to measure financial development. Those data are, however, available only at annual level (Bahadir and Valev, 2015). Note that we do not use other measures such as liquid liabilities, commercialcentral bank ration, and property rights protection because they are also only available at annual level.

${ }^{10}$ The GDP growth rate for emerging markets is proxied by the quarterly rate of change of the Industrial Production Index, since quarterly GDP growth data are not available in the IFS database.

${ }^{11}$ See, Kaminsky and Schmukler (2002), for a more detailed overview.

${ }^{12}$ See, Gande and Parsley (2010), for a more detailed description of the comprehensive credit rating.
} 
iii) Economic, financial, and political risk factors: Following previous studies, we consider three broad categories of local factor risks: political, financial and economic risks (e.g. Jüttner et al., 2006; Huang et al., 2015; Duyvesteyn et al., 2016). We use the three measures of risk compiled by the International Country Risk Guide (ICRG) of the Political Risk Services (PRS). The ICRG score for each country is calculated by considering 22 variables grouped into three subcategories of risk: political risk rating (PR), financial risk rating (FR), and economic risk rating (ER). The ICRG score for the political subcategory ranges from 0 to 100 and from 0 to 50 for economic and financial risk and higher values indicate lower risk. Our measure of risk is the quarterly percentage change in political, financial, and economic risk ratings.

The global factors include the following variables:

i) Global bond market returns: We use returns (measured in US dollars) on the Bank of America Merrill Lynch Global Government Index as a proxy for the returns on a benchmark global bond portfolio. ${ }^{13}$ Data are from Datastream International.

ii) Global liquidity conditions: We use the U.S. federal funds rate as a proxy for global liquidity conditions. Data are from the Federal Reserve System database. We use the quarterly change in the U.S. federal funds rate as an indicator of the tightening (loosening) of global liquidity conditions.

iii) Global bond market uncertainty: Previous studies have shown that uncertainty of the global bond market (measured by implied volatility) may influence bond markets returns (Piljak, 2013). It is proxied by the quarterly rate of change in the Merrill Lynch Option Volatility Estimate (MOVE) Index, which is a widely-followed measure of government bond volatility (Dimic et al., 2016). The MOVE index is a yield curve weighted index of

\footnotetext{
${ }^{13}$ See http://www.federatedinvestors.com/FII/leaf/display.do?category=Benchmark_Glossary for the requirements of a country inclusion in the index.
} 
the normalized implied volatility on 1-month Treasury options weighted on two-, five-, ten-, and thirty-year contracts. Data are from Datastream International.

iv) Global financial conditions: Fricke and Menkhoff (2015) show that financial conditions should be considered as determinants of bond excess returns. In our empirical analysis, we use the Chicago Fed's National Financial Conditions Index (NFCI) as a comprehensive indicator of the financial conditions in the US money, debt, and equity markets, as well as the traditional and shadow banking systems. ${ }^{14}$

\subsection{Summary statistics}

Table 1 reports summary statistics for the full sample, and developed and emerging markets subsamples, while Table 2 provides the correlation matrix. As expected, government total bond returns are higher $(2.24 \%)$ in emerging markets compared to developed markets $(1.56 \%)$. The volatility of these returns is also higher for emerging markets. With respect to the financial development measure, developed economies are, on average, much more financially developed (165\%) than emerging economies (66\%). ${ }^{15}$ Another notable difference is the average comprehensive credit rating for developed markets (20.07) is about double the corresponding rating of emerging markets (11.85).

\section{"Insert Table 1 about here" \\ "Insert Table 2 about here"}

Considering the full sample, we note high uncertainty in the global bond market $(1.75 \%)$ and an expansion in the global market liquidity conditions (on average negative change in the Fed funds rate $-2.4 \%$ ). This is consistent with the unconventional monetary policy (zero-bound interest

\footnotetext{
${ }^{14}$ By construction, the NFCI has an average value of zero and a standard deviation of one over a sample period extending back to 1973. Positive (negative) values of the index indicate financial conditions which are tighter (looser) than on average.

${ }^{15}$ Figure A1 (Appendix A) plots the dynamic evolution of average bond returns and financial development variables.
} 
rate policy) conducted by various central banks in the aftermath of the global financial crisis 2008-2009 and the Eurozone debt crisis. The negative average value $(-0.3 \%)$ of global financial condition index suggests highly fluid financial conditions for global financial markets. In terms of country risks, the risk indicators (economic, financial, and political risks) indicate a slight increase of financial and political risk, as the quarterly changes of respective ICRG risk scores are, on average, negative. ${ }^{16}$ The same situation is observed for developed markets, while for emerging markets only the political risk increases.

\section{Methodology}

Quantile Regression (QR) is a powerful tool to examine the conditional dependence of specific quantiles of the dependent variable with respect to the conditioning variables. ${ }^{17}$ In our case, the QR approach has the important advantage that it can estimate differences in the impact of the financial development on the bond returns under different market conditions, including bad (lower quantile) and good (upper quantile) market conditions.

We use a panel quantile regression methodology as follows: ${ }^{18}$

$$
\begin{aligned}
& Q_{\theta}\left(y_{i t} \mid x_{i t}\right)=\alpha_{\theta}+\beta_{1 \theta} F D_{i t}+\beta_{2 \theta} I N F_{i t}+\beta_{3 \theta} G D P_{i t}+\beta_{4 \theta} C C R_{i t}+\beta_{5 \theta} \Delta E R_{i t}+\beta_{6 \theta} \Delta F R_{i t} \\
& +\beta_{7 \theta} \Delta P R_{i t}+\beta_{8 \theta} G B R_{t}+\beta_{9 \theta} \Delta G L I Q_{t}+\beta_{10 \theta} \Delta G U_{t}+\beta_{11 \theta} G F C_{t}+\varepsilon_{i, t}
\end{aligned}
$$

where $i$ refers to countries; $t$ to time; $y_{i t}$ is the return on government bond price index of country $i$ at time $t, Q_{\theta}\left(y_{i t} \mid x_{i t}\right)$ refers to $\theta^{\text {th }}$ conditional quantile of $y_{i t}$ given a set of independent variables denoted with $x_{i t}$; FD is a measure of financial development; INF is inflation, GDP refers to

\footnotetext{
${ }^{16}$ In the ICRG methodology, the higher values of risk score indicate lower risk.

17 See, Koenker (2005) and Koenker and Hallock (2001) for further details on the use of quantile regressions.

${ }^{18}$ Pires et al. (2015) use panel quantile regressions to examine the determinants of credit default swaps.
} 
GDP growth; CCR is comprehensive credit rating; $E R, F R$, and $P R$ refer to economic, financial and political risk scores, respectively; GBR, GLIQ, GU, and GFC denote global bond market returns, global liquidity, global bond market uncertainty, and global financial conditions variables, respectively.

Model (1) is estimated at seven different quantiles $(\theta)$, namely, the 5th, 10th, 25th, 50th, 75th, 90th, and 95th quantile. We correct for cross-sectional correlation of the error term using bootstrapped cluster standard errors. ${ }^{19}$ The model is estimated for the full sample, and separately for developed and emerging markets subsamples.

The estimation of QR model involves calculation of a goodness of fit measure, the Pseudo R-squared (see, Koenker and Machado, 1999). The Pseudo R-squared for quantile regression is analogous to the R-squared measure for ordinary least squares (OLS) regression and it is defined as follows:

$$
R^{2}(\theta)=1-\frac{\sum_{i=1}^{n}\left|y_{i}-x_{i}^{\prime} \hat{\beta}_{\theta}\right|}{\sum_{i=1}^{n}\left|y_{i}-Q_{\theta}(y)\right|} \in(0,1)
$$

where $\sum_{i=1}^{n}\left|y_{i}-x_{i}^{\prime} \hat{\beta}_{\theta}\right|$ is the sum of the absolute residuals of $y_{i}$ about the estimated conditional quantile, while $\sum_{i=1}^{n}\left|y_{i}-Q_{\theta}(y)\right|$ denotes the sum of the absolute difference of $y_{i}$ about the unconditional quantile of $y$, for a given $\theta, Q_{\theta}(y)$.

\footnotetext{
${ }^{19}$ The bootstrap's clustered standard errors are obtained with 250 bootstrap replications.
} 


\section{Empirical results}

\subsection{Conditional mean regression analysis}

Before presenting the results from QR, we estimate the relationship using the classical conditional mean approach. The conditional mean regression serves as a benchmark for comparison purposes to the QR model. First, we estimate the model with panel least-squares regression that includes country-fixed effects and test the hypothesis that the country effects are jointly equal to zero. The null hypothesis cannot be rejected and therefore the model is estimated using a pooled OLS regression. ${ }^{20}$ Table 3 reports these results for the full sample and subsamples of developed and emerging markets.

\section{"Insert Table 3 about here"}

The results show that the degree of domestic financial development is not a statistically significant determinant of bond returns for any of the samples considered. The conditional mean regression assumes a uniform effect of financial development on government bond returns. However, this effect may not be uniform and could depend on bond markets conditions. This is a fundamental issue that we explore below in the paper. Concerning the other explanatory variables, a country's credit rating is not significantly related to changes in bond prices. While conditional mean regression assumes a uniform effect for the credit rating, as it is shown in the next section, this effect is not uniform as investors react differently to improved credit ratings depending on market conditions. Other notable results from Table 3 are that investors respond positively to improvements in global bond market returns. The response is negative with respect to higher global bond market uncertainty and to worsening of global financial conditions (as indicated by the coefficients for

\footnotetext{
${ }^{20}$ Given that the panel model includes global variables common to all countries; it is not possible to include timespecific fixed effects in the full model specification because such inclusion would result in singularity. For the restricted model specification (excluding global factors), time-specific fixed effects were included as a robustness check and the main results were robust after controlling for time-specific effects.
} 
variables proxied by the MOVE Index and the NFCI Index, respectively). Finally, government bond price changes respond positively to improvements in domestic financial and political risks.

\subsection{Quantile regression analysis}

Results from applying the panel QR methodology are presented for the full sample (Table 4) and, separately, for the developed (Table 5) and emerging markets subsample (Table 6). Appendix B provides graphical representation of the quantile plot of estimated slope coefficients and $95 \%$ confidence intervals. First the explanatory power of the model as indicated by the goodness of fit (the Pseudo R-squared) is higher for developed markets than for emerging markets in all quantiles. This is in line with Rioja and Valev (2004) and Henderson et al. (2013), who argue that the development stage of a given country plays an important role in how financial development affects its economic growth. Furthermore, the highest value of the Pseudo R-squared is obtained for the top quantile (0.95) and, in the case of the full and developed-country samples, the Pseudo R-squared increases as market conditions change from bad (lower quantiles) to good (higher quantiles).

"Insert Table 4 about here"

"Insert Table 5 about here"

"Insert Table 6 about here"

The QR results for the full sample (Table 4) show that relationship between financial development and government bond returns is positive and statistically significant for the upper quantiles (good market conditions) and negative and significant for the lowest (0.05) quantile (extremely bad market conditions); the effect is not significant in median quantile (normal market conditions). This is also the case for emerging economies (Table 6). The relationship is, however, statistically significant only for the upper quantiles (good market conditions) for developed markets (Table 5). The overall conclusion is that the effect is negative for lower quantiles, positive for upper quantiles 
and insignificant for the middle. This result suggests that during periods of high bond market returns, investors perceive increases in financial development to be an advantage, while in periods when returns are very low, greater financial development and exposure to financial shocks (domestic or foreign) is considered as a handicap by investors. This finding is consistent with an asymmetric impact of financial development on government bond returns and documented nonlinearities in the relationship between financial development and economic growth (e.g. Arcand et al., 2012; Beck et al., 2014). The asymmetric impact is related to the argument that despite a positive effect of financial development on economic growth, a rapid increase in private credit can be seen as a reliable predictor of a financial crisis (Demirgüç-Kunt and Detragiache, 2005; Jorda et al., 2011), where excessive growth in private credit may lead to financial instability and, consequently affect bond markets negatively.

The next question is whether the positive (negative) effect during good (bad) market conditions is significantly different from normal condition. In this respect, we test whether the slopes of the estimated coefficients change across quantiles. In particular, we focus on the extreme quantiles on the left ( 0.05 quantile) and right side ( 0.95 quantile) of the distribution and test their equality to the median quantile. We test two hypotheses: (i) the slopes for the 0.05 and 0.50 quantiles are equal and (ii) the slopes for the 0.50 and 0.95 quantiles are equal. Table 7 presents results of tests for inter-quantile differences. For the full sample and emerging markets subsample, the estimated slopes are statistically different from each other in both cases. This implies that the effect of financial development on government bond returns in good and bad market conditions is different from the effect in normal conditions. For developed markets, there is evidence for significant differences only for the second test. The difference between emerging and developed markets can be related to the finding of Masten et al. (2008) that the positive effect of financial development on 
growth is higher in less developed countries (revealed by the estimated coefficients in Tables 5 and 6).

\section{"Insert Table 7 about here"}

Turning to the role of local and global factors, the results for the full sample show that global factors are more dominant than local ones: global bond returns, global financial conditions and global market uncertainty are uniformly significant (with a few exceptions) across all quantiles. On the other hand, most coefficient estimates for local factors (with the exception of credit rating) are insignificant across most quantiles. This result is consistent with the findings of Martell (2008) and Longstaff et al. (2011). Furthermore, this result might reflect an increasing level of government bond market integration, since emerging bond markets are becoming increasingly integrated with global financial markets over time and therefore becoming more exposed to influence of global factors (see, Agur et al., 2018). For instance, Šimović et al. (2016) find that government bond markets of the more advanced post-transition countries in the Eastern European region have achieved higher levels of integration with the Eurozone bond market.

When we compare the results for developed and emerging economies, there is considerable variation in the importance of local and global factors. The most influential factors for developed markets are global bond market returns and global financial conditions (significant for all quantiles), while the most consistently significant factors for emerging markets are sovereign credit ratings and global bond market uncertainty (significant except for one quantile). For emerging economies, the pattern of estimated coefficients for credit ratings shows a uniform decrease in size turning from positive during periods when bond price changes are low (low bond market returns) to negative during periods of high returns. The positive sign during periods when bond returns are lowest indicates that investors pay attention to sovereign rating upgrades (downgrades) as a positive signal that prompts them to invest in sovereign bonds (negative signal to sell). A credit rating 
upgrade by one grade increases bond returns by $1.7 \%$ for the lowest returns ( 0.05 quantile). During periods of very high market returns ( 0.95 quantile) investors may not respond to credit upgrades by buying bonds because during these periods they may be interested in securing their gains and thus may view the upgrade as confirmation of the country's past performance. Thus, an upgrade in this case may act as a signal for them to take stock of their realized gains by selling bonds and lowering prices. Finally, the measures of domestic economic, financial and political risk are generally not significant in explaining bond returns. This may be because of the slow movement of these variables from one quarter to the next. Domestic macroeconomic conditions (inflation and growth) are significant for developed economies but less significant for emerging economies.

\subsection{Robustness checks}

We conduct several robustness checks of our results to address concerns about outliers and structural changes over time in the relationship between financial development and government bond returns. In the first case, we consider whether Argentina might confound our findings, because of its extremely low level of financial development ${ }^{21}$ and the sovereign bond default in 2001 . To mitigate this concern, we repeat the quantile regression analysis by excluding Argentina from the full sample and the emerging markets subsample. The results remain qualitatively the same and corroborate our previous findings. ${ }^{22}$

The second robustness check is related to possible changes in the effect of financial development over time. There is evidence that the strength of the financial development-growth relationship varies over time. For instance, Rousseau and Wachtel (2011) argue that inadequate financial liberalization processes (not followed with regulatory development) in certain countries over

\footnotetext{
${ }^{21}$ The mean value of private credit/GDP ratio (financial development measure) for Argentina is $16.8 \%$, while the corresponding value for the full sample is $129.8 \%$ and for emerging markets subsample is $66.4 \%$.

${ }^{22}$ The results are not reported for sake of brevity, but are available from the authors upon request.
} 
time has led to credit boom and financial instability, which might mitigate or eliminate the positive effects of financial development on growth. Furthermore, our sample period covers the global financial crisis of 2008 - 2009 and Eurozone debt crisis. Both crises brought to the surface concerns regarding the excessive size of the financial sector and its negative effects on financial stability. To address this, we divide our sample into two subperiods: (i) Q2: 1999 - Q2:2008, and (ii) Q3:2008 - Q1: 2015. Due to the short time period and quarterly frequency of the data, we have relatively small number of observations in subperiods. The results (available on request) for the full sample and both (emerging and developed markets) subsamples show that the nature of the relationship has not changed qualitatively over time: financial development has a positive effect on government bond returns in good market conditions, while the effect is negative in bad market conditions. However, in the full sample of countries and emerging markets subsample, the strength of the relationship is weaker in the first subperiod as the effect is statistically significant only during the good market conditions. However, the effect in the second subperiod is significant in both good and bad market conditions. Moreover, in the developed market subsample the significant effect in good market conditions (observed in the full time period) is no longer evident in the two subperiods.

Third, we examine whether the results are robust after controlling for the effects of the global business cycle. For this purpose, we include the quarterly growth of global GDP as proxy for the global business cycle. The coefficient estimate is negative and significant for all quantiles which suggests that global growth is associated with negative changes in bond prices when investors turn to stock markets during periods of economic growth reducing demand for bonds. The main results (available on request) on the sign and significance of financial development remain unchanged for the full sample and both subsamples (developed and emerging markets). 


\section{Conclusions}

This paper studies the effect of financial development on government bond returns in developed and emerging markets and whether this effect differs under different market conditions. In addition to financial development, it analyzes the degree to which other country-specific local and global factors might affect government bond returns.

The results lead to several conclusions. First, the effect of financial development on government bond returns depends on market conditions and it differs between developed and emerging markets. For the full sample and the emerging markets sample, the effect is positive and significant in good market conditions, while the effect is negative (and significant) in bad market conditions. For developed economies, financial development is significant only in good market conditions. Second, by focusing on extreme quantiles on the left and right sides of the distribution and testing their equality with the median quantile, we find that the effect of financial development on government bond returns in good and bad market conditions is significantly different from its effect in normal conditions. These findings are informative and useful in understanding the linkage between financial development, economic growth, and government bond returns and complement in a substantial manner prior literature. Third, our results indicate that there is considerable variation among emerging and developed markets in terms of the importance of certain local and global factors in determining government bond returns. The most influential factors for developed markets are global bond market returns and global financial conditions, while the most prominent factor for emerging markets is sovereign credit rating. Those factors are relevant in determining government bond returns regardless of whether the market conditions are good, normal, or bad. Overall, differences in the results for emerging and developed markets indicate that the stage of a country's development and level of financial integration should be considered as important elements in the ongoing debate regarding the relative importance of global versus local factors. 
In summary, our findings have important policy implications. In light of discussions concerning financial stability, they underscore the need to consider the state of market conditions in determining the relationship between financial development and government bond returns. Our results support the argument that greater financial development is associated with higher government bond returns in good and normal market conditions. It has been argued, however, that beyond a point higher credit to the private sector may increase repayment difficulties and lower bond returns. This is the case in emerging markets where domestic credit has expanded so fast that the private sector is having great difficulty in paying it back. ${ }^{23}$ In light of these arguments and considering that credit growth is identified as "the single best predictor of financial instability" (see, Jorda et al., 2011), our study provides useful insights for policymakers in terms of assessing the potential risks that might affect financial stability and increase possibility of sovereign default.

\footnotetext{
${ }^{23}$ See, for instance, The Economist article (26th March 2016) "Red ink rising".
} 


\section{References}

Afonso, A., Jalles, J.T., 2019. Quantitative easing and sovereign yield spreads: Euro-area timevarying evidence. Journal of International Financial Markets, Institutions and Money 58, $208-224$.

Agur, I, Chan, M., Goswami, M., Sharma, S., 2018. On international integration of emerging sovereign bond markets. Emerging Markets Review, https://doi.org/10.1016/j.ememar.2018.11.006.

Alfaro, L., Chanda, A., Kalemli-Ozcan, S., Sayek, S., 2004. FDI and economic growth: The role of local financial markets. Journal of International Economics 64, 89-112.

Arcand, J.-L., Berkes, E., Panizza, U., 2012. Too much finance? IMF Working Paper 12/161.

Bahadir,B., Valev, N., 2015. Financial development convergence. Journal of Banking and Finance $56,61-71$.

Baur, D.G., 2013. The structure and degree of dependence: A quantile regression approach. Journal of Banking and Finance 37, 786-798.

Baur, D., Schulze, N., 2009. Financial market stability - A test. Journal of International Financial Markets, Institutions and Money 19, 506-519.

Beck, T., Degryse, H., Kneer, C., 2014. Is more finance better? Disentangling intermediation and size effects of financial systems. Journal of Financial Stability 10, 50-64.

Beck, R., Georgiadis, G., Straub, R., 2014. The finance and growth nexus revisited. Economics Letters $124,382-385$.

Beck, T., Demirgüç-Kunt, A., Levine, R., 2003. Law, endowments, and finance. Journal of Financial Economics 70, 137-181.

Beck, T., Levine, R., Loayza, N., 2000. Finance and the sources of growth. Journal of Financial Economics 58, 261-300.

Beck, T., Levine, R., 2004. Stock markets, banks, and growth: Panel evidence. Journal of Banking and Finance 28, 423-442. 
Chinn, M. D., Ito, H., 2006. What matters for financial development? Capital controls, institutions, and interactions. Journal of Development Economics 81, 163-192.

Christiansen, C., 2007. Volatility-spillover effect in European bond markets. European Financial Management 13, 923-948.

Claessens, S., Klingebiel, D., Schmukler, S. L., 2007. Government bonds in domestic and foreign currency: The role of institutional and macroeconomic factors. Review of International Economics $15,370-413$.

Csonto, B., 2014. Emerging market sovereign bond spreads and shifts in global market sentiment. Emerging Markets Review 20, 58-74.

Csonto, B, Ivaschenko, I., 2013. Determinants of sovereign bond spreads in emerging markets: Local fundamentals and global factors vs. ever-changing misalignments. IMF Working Paper WP/13/164.

Dailami, M., Masson, P.R., Padou, J.J., 2008. Global monetary conditions versus country-specific factors in determination of emerging market debt spreads. Journal of International Money and Finance 27, 1325-1336.

Dawood, M., Horsewood, N., Strobel, F., 2017. Predicting sovereign debt crises: An Early Warning System approach. Journal of Financial Stability 28, 16-28.

Dellas, H., Hess, M., 2005. Financial development and stock returns: A cross-country analysis. Journal of International Money and Finance 24, 891-912.

Demirgüç-Kunt, A., Detragiache, E., 2005. Cross-country empirical studies of systemic banking distress: A survey. In: Davis, P. (Ed.), Financial Instability, Asset Prices and Credit. National Institute Economic Review.

Dimic, N., Kiviaho, J., Piljak, V., Äijö, J., 2016. Impact of financial market uncertainty and macroeconomic factors on stock-bond correlation in emerging markets. Research in International Business and Finance 36, 41-51.

Durusu-Ciftci, D., Ispir, M. S., Yetkiner, H., 2017. Financial development and economic growth: Some theory and more evidence. Journal of Policy Modeling 39, 290-306. 
Duyvesteyn, J., Martens, M, Verwijmeren, P., 2016. Political risk and expected government bond returns. Journal of Empirical Finance 38, 498-512.

Fink, G., Haiss, P., Histofrova, S., 2003. Bond markets and economic growth. IEF working paper No. 49, 1-31.

Fricke, C., Menkhoff, L., 2015. Financial conditions, macroeconomic factors and disaggregated bond excess returns. Journal of Banking and Finance 58, 80-94.

Gande, A., Parsley, D., 2010. Sovereign credit ratings, transparency and international portfolio flows. MPRA Paper no. 21118.

Gennaioli, N., Martin, A., Rossi, S., 2014. Sovereign default, domestic banks, and financial institutions. Journal of Finance 69, 819-866.

Gómez-Puig, M., 2009a. The immediate effect of monetary union over EU-15's sovereign debt yield spreads. Applied Economics 41, 929-939.

Gómez-Puig, M., 2009b. Systemic and idiosyncratic risk in EU-15 sovereign yield spreads after seven years of Monetary Union. European Financial Management 15, 971-1000.

Henderson, D.J., Papageorgiou, C., Parmeter, C.F., 2013. Who benefits from financial development? New methods, new evidence. European Economic Review 63, 47-67.

Huang, T., Wu, F., Yu, J., Zhang, B., 2015. International political risk and government bond pricing. Journal of Banking and Finance 55, 393-405.

Jaramillo, L., Weber, A., 2013. Bond yields in emerging economies: It matters what state you are in. Emerging Markets Review 17, 169-185.

Jorda, O., Schularick, M., Taylor, A.M., 2011. Financial crises, credit booms, and external imbalances: 140 years of lessons. IMF Economic Review 59, 340-378.

Jüttner, D.H., Chung, D., Leung, W., 2006. Emerging market bond returns - An investor perspective. Journal of Multinational Financial Management 16, 105-121.

Kaminsky G., Schmukler, S.L., 2002. Emerging market instability: Do sovereign ratings affect country risk and stock returns? The World Bank Economic Review 16, 171-195. 
Kennedy, M., Palerm, A., 2014. Emerging market bond spreads: The role of global and domestic factors from 2002 to 2011. Journal of International Money and Finance 43, 70-87.

Kim, S-J., Lucey, B. M., Wu, E., 2006. Dynamics of bond market integration between established and accession European Union countries. Journal of International Financial Markets, Institutions and Money 16, 41-56.

Koenker, R., 2005. Quantile regression. Econometric Society Monograph Series. Cambridge University Press, New York.

Koenker, R., Bassett, G., 1978. Regression quantiles. Econometrica 46, 33-50.

Koenker, R., Hallock, K.F., 2001. Quantile regression. Journal of Economic Perspectives 15, 143156.

Koenker, R., Machado, J., 1999. Goodness of fit and related inference processes for quantile regression. Journal of the American Statistical Association 94, 1296-1310.

Kose, A., Prasad, E., Rogoff, K., Wei, S.-J., 2009. Financial globalization: An appraisal. IMF Staff Papers 56, 8-62.

Levine, R., 1997. Financial development and economic growth: Views and agenda. Journal of Economic Literature 35, 688-726.

Levine, R., Loayza, N., Beck, T., 2000. Financial intermediation and growth: Causality and causes. Journal of Monetary Economics 46, 31-77.

Levine, R., Zervos, S., 1998. Stock markets, banks, and economic growth. American Economic Review 88, 537-558.

Levine, R., 2005. Finance and growth: theory and evidence. In: Aghion, P., Durlauf, S. (Eds.), Handbook of Economic Growth, Vol. 1, first ed. Elsevier, 865-934, chapter 12.

Longstaff, F., Pan, J., Pedersen, L., Singleton, K.J., 2011. How sovereign is sovereign credit risk? American Economic Journal-Macroeconomics 3, 75-103.

Ma, Y., Lin, X., 2016. Financial development and the effectiveness of monetary policy. Journal of Banking and Finance 68, 1-11. 
Martell, R., 2008. Understanding common factors in domestic and international bond spreads. Review of Finance 12, 362-389.

Masten, A., Coricelli, F., Masten, I., 2008. Non-linear growth effects of financial development: does financial integration matter? Journal of International Money and Finance 27, 295-313.

Piljak, V., 2013. Bond markets co-movement dynamics and macroeconomic factors: Evidence from emerging and frontier markets. Emerging Markets Review 17, $29-43$.

Piljak, V., Swinkels, L., 2017. Frontier and emerging government bond markets. Emerging Markets Review 30, 232-255.

Pires, P., Pereira, J.P., Martins, L.F., 2015. The empirical determinants of credit default swap spreads: a quantile regression approach. European Financial Management 21, 556-589.

Pradhan, R.P., Arvin, M.B., Bennett, S.E., Nair, M., Hall, J.H., 2016. Bond market development, economic growth and other macroeconomic determinants: panel VAR evidence. AsiaPacific Financial Markets 23, 175-201.

Rioja, F., Valev, N., 2004. Finance and the sources of growth at various stages of economic development. Economic Inquiry 42, 127-140.

Rousseau, P.L., Wachtel, P., 2000. Equity markets and growth: Cross-country evidence on timing and outcomes, 1980-1995. Journal of Business and Finance 24, 1933-1957.

Rousseau, P.L., Wachtel, P., 2011. What is happening to the impact of financial deepening on economic growth? Economic Inquiry 49, 276-288.

Shen, C.-H., Lee, C.-C., 2006. Same financial development yet different economic growth - Why? Journal of Money, Credit and Banking 38, 1907-1944.

Šimović, P.P., Tkalec, M., Vizek, M., Lee, J., 2016. Time-varying integration of the sovereign bond markets in European post-transition economies. Journal of Empirical Finance 36, 3040.

Thumrongvit, P., Kim, Y., Pyun, C.S., 2013. Linking the missing market: The effect of bond markets on economic growth. International Review of Economics and Finance 27, 529-541. 
Wachtel, P., 2001. Growth and finance: What do we know and how do we know it? International Finance 4(3), 335-362. 
Table 1. Descriptive statistics

\begin{tabular}{|c|c|c|c|c|c|c|}
\hline Variable & $\begin{array}{c}\text { Variable } \\
\text { abbreviation }\end{array}$ & Mean & Median & $\begin{array}{r}\text { Standard } \\
\text { deviation }\end{array}$ & Skewness & Kurtosis \\
\hline \multicolumn{7}{|l|}{ Full sample } \\
\hline Bond returns & $y$ & 1.804 & 1.628 & 6.618 & -0.386 & 28.091 \\
\hline Financial development & $F D$ & 129.835 & 137.050 & 62.32 & -0.193 & 2.194 \\
\hline Inflation & $I N F$ & 0.885 & 0.587 & 1.528 & 5.394 & 51.346 \\
\hline GDP growth & $G D P$ & 1.454 & 1.728 & 4.571 & 0.460 & 11.744 \\
\hline Sovereign credit rating & $C C R$ & 17.140 & 20.000 & 4.757 & -1.187 & 3.880 \\
\hline Economic risk & $E R$ & 0.106 & 0.000 & 4.019 & 1.896 & 34.229 \\
\hline Financial risk & $F R$ & -0.003 & 0.000 & 3.731 & 0.709 & 24.119 \\
\hline Political risk & $P R$ & -0.065 & 0.000 & 1.717 & 0.726 & 14.578 \\
\hline Global bond market returns & $G B R$ & 1.122 & 0.620 & 3.611 & 0.587 & 2.669 \\
\hline Global liquidity conditions & GLIQ & -2.388 & 0.000 & 22.916 & -0.346 & 4.247 \\
\hline Global bond market uncertainty & $G U$ & 1.752 & -4.091 & 19.860 & 1.331 & 5.560 \\
\hline Global financial conditions & $G F C$ & -0.300 & -0.461 & 0.634 & 2.325 & 8.911 \\
\hline \multicolumn{7}{|l|}{ Developed markets subsample } \\
\hline Bond returns & $y$ & 1.562 & 1.163 & 5.786 & 0.281 & 3.194 \\
\hline Financial development & $F D$ & 165.037 & 165.100 & 39.618 & 0.256 & 2.710 \\
\hline Inflation & INF & 0.442 & 0.431 & 0.605 & 0.080 & 4.990 \\
\hline GDP growth & $G D P$ & 1.584 & 1.919 & 2.377 & -1.078 & 5.274 \\
\hline Sovereign credit rating & $C C R$ & 20.078 & 21.000 & 1.913 & -3.230 & 14.641 \\
\hline Economic risk & $E R$ & -0.002 & 0.000 & 2.979 & -0.569 & 15.730 \\
\hline Financial risk & $F R$ & -0.143 & 0.000 & 2.929 & -0.211 & 8.945 \\
\hline Political risk & $P R$ & -0.069 & 0.000 & 1.335 & 0.536 & 9.375 \\
\hline \multicolumn{7}{|l|}{ Emerging markets subsample } \\
\hline Bond returns & $y$ & 2.240 & 2.136 & 7.885 & -0.918 & 37.655 \\
\hline Financial development & $F D$ & 66.472 & 57.400 & 42.467 & 0.789 & 2.646 \\
\hline Inflation & $I N F$ & 1.682 & 1.292 & 2.213 & 3.946 & 26.199 \\
\hline GDP growth & $G D P$ & 1.221 & 1.147 & 6.950 & 0.534 & 6.106 \\
\hline Sovereign credit rating & $C C R$ & 11.853 & 13.000 & 3.644 & -1.293 & 5.024 \\
\hline Economic risk & $E R$ & 0.303 & 0.000 & 5.406 & 2.281 & 26.369 \\
\hline Financial risk & $F R$ & 0.248 & 0.000 & 4.843 & 0.894 & 21.453 \\
\hline Political risk & $P R$ & -0.057 & 0.000 & 2.247 & 0.698 & 11.822 \\
\hline
\end{tabular}

This table reports descriptive statistics for the full sample, and subsamples of developed and emerging markets from Q2:1999 to Q1:2015. Total number of quarterly observations is 1792 for the full sample (1152 for developed and 640 for emerging markets). Variables are defined in Section $3 ; y$ is the quarterly return on government bond market index; $F D$ is a measure of financial development; $I N F$ is inflation, GDP refers to GDP growth; $C C R$ is comprehensive credit rating; $E R, F R$, and $P R$ refer to changes in economic, financial and political risk scores, respectively; $G B R, G L I Q, G U$, and $G F C$ denote global bond market returns, changes in global liquidity, changes in global bond market uncertainty, and global financial conditions variables, respectively. Global factors for the developed and emerging markets subsamples are the same as for the full sample. 
Table 2. Correlation matrix

Panel A. Full sample

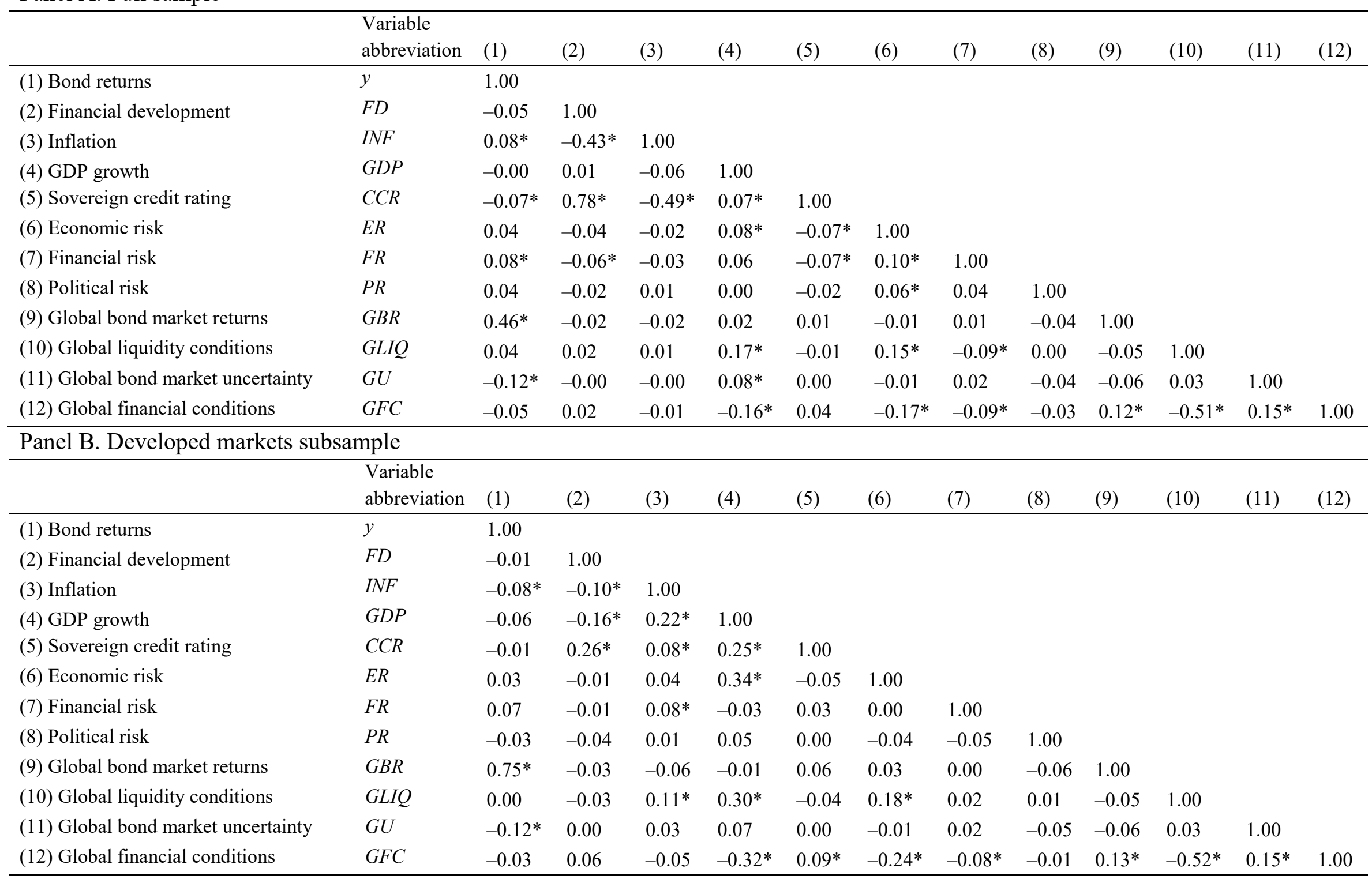


Panel C. Emerging markets subsample

\begin{tabular}{|c|c|c|c|c|c|c|c|c|c|c|c|c|c|}
\hline & $\begin{array}{l}\text { Variable } \\
\text { abbreviation }\end{array}$ & (1) & (2) & (3) & (4) & (5) & (6) & (7) & (8) & (9) & (10) & (11) & (12) \\
\hline (1) Bond returns & $y$ & 1.00 & & & & & & & & & & & \\
\hline (2) Financial development & $F D$ & -0.06 & 1.00 & & & & & & & & & & \\
\hline (3) Inflation & $I N F$ & $0.14^{*}$ & $-0.34 *$ & 1.00 & & & & & & & & & \\
\hline (4) GDP growth & $G D P$ & 0.03 & 0.06 & -0.10 & 1.00 & & & & & & & & \\
\hline (5) Sovereign credit rating & $C C R$ & -0.09 & $0.63^{*}$ & $-0.46^{*}$ & 0.03 & 1.00 & & & & & & & \\
\hline (6) Economic risk & $E R$ & 0.06 & -0.03 & -0.06 & 0.01 & -0.09 & 1.00 & & & & & & \\
\hline (7) Financial risk & $F R$ & 0.09 & -0.07 & -0.10 & 0.10 & $-0.11^{*}$ & $0.16^{*}$ & 1.00 & & & & & \\
\hline (8) Political risk & $P R$ & $0.11^{*}$ & -0.03 & 0.02 & -0.01 & -0.07 & $0.12 *$ & $0.10^{*}$ & 1.00 & & & & \\
\hline (9) Global bond market returns & $G B R$ & 0.10 & -0.03 & -0.01 & 0.05 & -0.01 & -0.06 & 0.02 & -0.03 & 1.00 & & & \\
\hline (10) Global liquidity conditions & $G L I Q$ & $0.10^{*}$ & -0.01 & -0.03 & $0.14^{*}$ & -0.02 & $0.14^{*}$ & $0.12 *$ & 0.00 & -0.05 & 1.00 & & \\
\hline (11) Global bond market uncertainty & $G U$ & $-0.13 *$ & 0.00 & -0.02 & $0.12 *$ & 0.01 & -0.03 & 0.02 & -0.05 & -0.06 & 0.03 & 1.00 & \\
\hline (12) Global financial conditions & $G F C$ & -0.09 & 0.00 & 0.00 & $-0.10^{*}$ & 0.06 & $-0.12^{*}$ & $-0.12 *$ & -0.06 & $0.13^{*}$ & $-0.52 *$ & $0.15^{*}$ & 1.00 \\
\hline
\end{tabular}

This table reports Pearson correlations for all the variables used in the empirical analysis. All variables are defined in Section 3. * denotes statistical significance at the $1 \%$ level. 
Table 3. Conditional mean approach

\begin{tabular}{|c|c|c|c|c|}
\hline \multirow[b]{2}{*}{ Variables } & \multirow[b]{2}{*}{ Variable abbreviation } & \multicolumn{3}{|c|}{ Pooled OLS } \\
\hline & & Full sample & Developed markets & Emerging markets \\
\hline Financial development & $F D$ & $\begin{array}{l}0.004 \\
(1.16)\end{array}$ & $\begin{array}{l}0.001 \\
(0.43)\end{array}$ & $\begin{array}{l}0.002 \\
(0.29)\end{array}$ \\
\hline Inflation & INF & $\begin{array}{c}0.373 * * * \\
(3.62)\end{array}$ & $\begin{array}{l}-0.189 \\
(-1.00)\end{array}$ & $\begin{array}{c}0.522 * * * \\
(3.31)\end{array}$ \\
\hline GDP growth & $G D P$ & $\begin{array}{l}-0.032 \\
(-1.05)\end{array}$ & $\begin{array}{c}-0.19 * * * \\
(-3.40)\end{array}$ & $\begin{array}{l}0.031 \\
(0.69)\end{array}$ \\
\hline Sovereign credit rating & $C C R$ & $\begin{array}{l}-0.073 \\
(-1.51)\end{array}$ & $\begin{array}{c}-0.07 \\
(-1.10)\end{array}$ & $\begin{array}{l}-0.031 \\
(-0.27)\end{array}$ \\
\hline Economic risk & $E R$ & $\begin{array}{l}0.042 \\
(1.23)\end{array}$ & $\begin{array}{l}0.009 \\
(0.22)\end{array}$ & $\begin{array}{l}0.041 \\
(0.71)\end{array}$ \\
\hline Financial risk & $F R$ & $\begin{array}{c}0.123 * * * \\
(3.32)\end{array}$ & $\begin{array}{c}0.125^{* * * *} \\
(3.28)\end{array}$ & $\begin{array}{l}0.123^{*} \\
(1.88)\end{array}$ \\
\hline Political risk & $P R$ & $\begin{array}{c}0.214^{* * * *} \\
(2.69)\end{array}$ & $\begin{array}{l}0.099 \\
(1.19)\end{array}$ & $\begin{array}{c}0.309 * * \\
(2.26)\end{array}$ \\
\hline Global bond market returns & $G B R$ & $\begin{array}{c}0.866 * * * \\
(22.68)\end{array}$ & $\begin{array}{l}1.22 * * * \\
(39.24)\end{array}$ & $\begin{array}{c}0.218 * * \\
(2.55)\end{array}$ \\
\hline Global liquidity conditions & GLIQ & $\begin{array}{l}0.007 \\
(0.99)\end{array}$ & $\begin{array}{l}-0.003 \\
(-0.58)\end{array}$ & $\begin{array}{c}0.033 * * \\
(2.09)\end{array}$ \\
\hline Global bond market uncertainty & $G U$ & $\begin{array}{c}-0.026 * * * \\
(-3.70)\end{array}$ & $\begin{array}{c}-0.013 * * \\
(-2.41)\end{array}$ & $\begin{array}{c}-0.046 * * * \\
(-2.94)\end{array}$ \\
\hline Global financial conditions & $G F C$ & $\begin{array}{c}-0.810 * * * \\
(-3.09)\end{array}$ & $\begin{array}{c}-1.330 * * * \\
(-6.04)\end{array}$ & $\begin{array}{l}-0.120 \\
(-0.20)\end{array}$ \\
\hline Constant & & $\begin{array}{l}1.10^{*} \\
(1.67)\end{array}$ & $\begin{array}{l}1.455 \\
(1.18)\end{array}$ & $\begin{array}{c}1.37 \\
(1.00)\end{array}$ \\
\hline $\mathrm{R}$-squared & & 0.25 & 0.58 & 0.07 \\
\hline
\end{tabular}

This table presents OLS regressions of quarterly government bond returns on the set of explanatory variables defined in Section 3 for the full sample, and subsamples of developed and emerging markets. The dependent variable is quarterly return on government bond market index. The explanatory variables are: FD is a measure of financial development; INF is inflation, GDP refers to GDP growth; CCR is comprehensive credit rating; ER, FR, and PR refer to changes in economic, financial and political risk scores, respectively; GBR, GLIQ, GU, and GFC denote global bond market returns, changes in global liquidity, changes in global bond market uncertainty, and global financial conditions variables, respectively. The numbers in parentheses are $\mathrm{t}-$ statistics. $*, * *, * * *$ denote statistical significance at the $10 \%$, $5 \%$, and $1 \%$ levels, respectively. 
Table 4. Quantile regression results for the full sample

\begin{tabular}{|c|c|c|c|c|c|c|c|c|}
\hline \multirow[b]{2}{*}{$\begin{array}{l}\text { Dependent variable: } \\
\text { government bond returns }\end{array}$} & \multirow[b]{2}{*}{ Variable abbreviation } & \multicolumn{7}{|c|}{ Quantile } \\
\hline & & 0.05 & 0.10 & 0.25 & 0.50 & 0.75 & 0.90 & 0.95 \\
\hline Financial development & $F D$ & $\begin{array}{c}-0.018 * * * \\
(-2.81)\end{array}$ & $\begin{array}{l}-0.008 \\
(-1.52)\end{array}$ & $\begin{array}{l}0.002 \\
(0.78)\end{array}$ & $\begin{array}{l}0.003 \\
(1.31)\end{array}$ & $\begin{array}{l}0.006 * * * \\
(2.61)\end{array}$ & $\begin{array}{c}0.014 * * * \\
(3.32)\end{array}$ & $\begin{array}{c}0.021 * * * \\
(3.24)\end{array}$ \\
\hline Inflation & $I N F$ & $\begin{array}{l}-0.487 \\
(-1.58)\end{array}$ & $\begin{array}{l}-0.482 \\
(-1.42)\end{array}$ & $\begin{array}{l}-0.096 \\
(-0.39)\end{array}$ & $\begin{array}{c}0.299 * * \\
(2.27)\end{array}$ & $\begin{array}{l}0.375 * * * \\
(2.59)\end{array}$ & $\begin{array}{l}0.588 * * * \\
(2.71)\end{array}$ & $\begin{array}{c}1.093 * * * \\
(2.59)\end{array}$ \\
\hline GDP growth & $G D P$ & $\begin{array}{c}-0.176 * * \\
(-2.39)\end{array}$ & $\begin{array}{c}-0.167 * * * \\
(-3.46)\end{array}$ & $\begin{array}{l}-0.059 \\
(-1.29)\end{array}$ & $\begin{array}{l}-0.025 \\
(-1.30)\end{array}$ & $\begin{array}{l}-0.040 \\
(-1.61)\end{array}$ & $\begin{array}{c}-0.069 * * \\
(-2.08)\end{array}$ & $\begin{array}{l}-0.050 \\
(-0.55)\end{array}$ \\
\hline Sovereign credit rating & $C C R$ & $\begin{array}{c}0.677 * * * \\
(3.93)\end{array}$ & $\begin{array}{c}0.268 * * \\
(2.56)\end{array}$ & $\begin{array}{l}-0.035 \\
(-0.53)\end{array}$ & $\begin{array}{c}-0.120 * * \\
(-2.29)\end{array}$ & $\begin{array}{c}-0.289 * * * \\
(-6.34)\end{array}$ & $\begin{array}{c}-0.574 * * * \\
(-7.16)\end{array}$ & $\begin{array}{c}-0.748 * * * \\
(-5.01)\end{array}$ \\
\hline Economic risk & $E R$ & $\begin{array}{l}0.115 \\
(1.32)\end{array}$ & $\begin{array}{l}0.029 \\
(0.34)\end{array}$ & $\begin{array}{l}-0.042 \\
(-0.73)\end{array}$ & $\begin{array}{l}-0.026 \\
(-0.65)\end{array}$ & $\begin{array}{l}-0.007 \\
(-0.25)\end{array}$ & $\begin{array}{l}0.046 \\
(0.63)\end{array}$ & $\begin{array}{l}0.093 \\
(1.07)\end{array}$ \\
\hline Financial risk & $F R$ & $\begin{array}{l}0.113 \\
(1.37)\end{array}$ & $\begin{array}{c}0.197 * * * \\
(3.11)\end{array}$ & $\begin{array}{c}0.168 * * * \\
(4.06)\end{array}$ & $\begin{array}{c}0.103 * * \\
(2.47)\end{array}$ & $\begin{array}{l}0.044 \\
(0.73)\end{array}$ & $\begin{array}{l}0.005 \\
(0.11)\end{array}$ & $\begin{array}{l}0.017 \\
(0.26)\end{array}$ \\
\hline Political risk & $P R$ & $\begin{array}{l}0.184 \\
(0.89)\end{array}$ & $\begin{array}{c}0.263 * * \\
(1.96)\end{array}$ & $\begin{array}{l}0.168 \\
(1.56)\end{array}$ & $\begin{array}{l}0.078 \\
(0.93)\end{array}$ & $\begin{array}{l}-0.058 \\
(-0.54)\end{array}$ & $\begin{array}{l}-0.075 \\
(-0.46)\end{array}$ & $\begin{array}{l}-0.176 \\
(-0.92)\end{array}$ \\
\hline Global bond market returns & $G B R$ & $\begin{array}{c}0.891 * * * \\
(12.12)\end{array}$ & $\begin{array}{c}0.872 * * * \\
(13.34)\end{array}$ & $\begin{array}{c}0.870 * * * \\
(15.67)\end{array}$ & $\begin{array}{c}1.016 * * * \\
(22.86)\end{array}$ & $\begin{array}{c}1.146 * * * \\
(24.81)\end{array}$ & $\begin{array}{c}1.193 * * * \\
(31.38)\end{array}$ & $\begin{array}{c}1.123 * * * \\
(22.83)\end{array}$ \\
\hline Global liquidity conditions & $G L I Q$ & $\begin{array}{l}-0.001 \\
(-0.04)\end{array}$ & $\begin{array}{l}-0.014 \\
(-1.08)\end{array}$ & $\begin{array}{l}-0.003 \\
(-0.44)\end{array}$ & $\begin{array}{l}0.008 \\
(1.61)\end{array}$ & $\begin{array}{l}-0.000 \\
(-0.04)\end{array}$ & $\begin{array}{l}0.010 \\
(1.47)\end{array}$ & $\begin{array}{c}0.022 * * \\
(1.97)\end{array}$ \\
\hline Global bond market uncertainty & $G U$ & $\begin{array}{c}-0.034 * * \\
(-2.54)\end{array}$ & $\begin{array}{c}-0.027 * * * \\
(-2.66)\end{array}$ & $\begin{array}{c}-0.028 * * * \\
(-3.60)\end{array}$ & $\begin{array}{c}-0.026 * * * \\
(-4.55)\end{array}$ & $\begin{array}{c}-0.018 * * * \\
(-3.04)\end{array}$ & $\begin{array}{c}-0.012 * \\
(-1.92)\end{array}$ & $\begin{array}{l}-0.009 \\
(-0.84)\end{array}$ \\
\hline Global financial conditions & $G F C$ & $\begin{array}{c}-4.701 * * * \\
(-6.27)\end{array}$ & $\begin{array}{c}-2.580 * * * \\
(-3.53)\end{array}$ & $\begin{array}{c}-1.266^{* * *} \\
(-3.96)\end{array}$ & $\begin{array}{c}-0.431 * * \\
(-2.24)\end{array}$ & $\begin{array}{l}-0.158 \\
(-0.58)\end{array}$ & $\begin{array}{c}0.800 * * \\
(2.06)\end{array}$ & $\begin{array}{c}2.062 * * * \\
(3.49)\end{array}$ \\
\hline Constant & & $\begin{array}{c}-16.860 * * * \\
(-5.20)\end{array}$ & $\begin{array}{c}-8.040 * * * \\
(-4.36)\end{array}$ & $\begin{array}{l}-1.509 \\
(-1.49)\end{array}$ & $\begin{array}{c}2.081 * * * \\
(2.76)\end{array}$ & $\begin{array}{c}6.910 * * * \\
(8.90)\end{array}$ & $\begin{array}{c}13.384 * * * \\
(10.87)\end{array}$ & $\begin{array}{c}17.325^{* * *} \\
(7.17)\end{array}$ \\
\hline Pseudo $\mathrm{R}^{2}$ & & 0.17 & 0.18 & 0.21 & 0.25 & 0.27 & 0.31 & 0.32 \\
\hline
\end{tabular}

This table presents the quantile regression estimates for the full sample according to the empirical model defined in Equation (1). Description of the variables is the same as in Table 3 . The numbers in parentheses are $\mathrm{t}$-statistics, computed using the bootstrapped cluster standard errors. *, **, *** denote statistical significance at the $10 \%, 5 \%$, and $1 \%$ levels, respectively. 
Table 5. Quantile regression results for developed markets

\begin{tabular}{|c|c|c|c|c|c|c|c|c|}
\hline \multirow[b]{2}{*}{$\begin{array}{l}\text { Dependent variable: } \\
\text { government bond returns }\end{array}$} & \multirow[b]{2}{*}{ Variable abbreviation } & \multicolumn{7}{|c|}{ Quantile } \\
\hline & & 0.05 & 0.10 & 0.25 & 0.50 & 0.75 & 0.90 & 0.95 \\
\hline \multirow[t]{2}{*}{ Financial development } & $F D$ & -0.010 & -0.007 & 0.000 & 0.000 & $0.004 *$ & $0.013 * * *$ & $0.014 * *$ \\
\hline & & $(-1.41)$ & $(-1.42)$ & $(0.00)$ & $(-0.01)$ & $(1.80)$ & $(2.80)$ & $(2.17)$ \\
\hline \multirow[t]{2}{*}{ Inflation } & $I N F$ & $-1.401 * * *$ & $-0.674 * *$ & -0.045 & 0.248 & -0.646 & -0.125 & 0.087 \\
\hline & & $(-3.00)$ & $(-2.13)$ & $(-0.19)$ & $(1.39)$ & $(-0.35)$ & $(-0.36)$ & $(0.18)$ \\
\hline \multirow[t]{2}{*}{ GDP growth } & $G D P$ & -0.203 & $-0.197 * *$ & $-0.283 * * *$ & $-0.170 * * *$ & $-0.171 * * *$ & -0.022 & 0.022 \\
\hline & & $(-1.46)$ & $(-2.27)$ & $(-4.75)$ & $(-2.96)$ & $(-2.79)$ & $(-0.23)$ & $(0.17)$ \\
\hline \multirow[t]{2}{*}{ Sovereign credit rating } & $C C R$ & $1.023 * * *$ & $0.652 * *$ & 0.132 & -0.054 & $-0.271 * *$ & $-0.741 * * *$ & $-0.975 * *$ \\
\hline & & $(3.78)$ & $(2.47)$ & $(0.98)$ & $(-0.66)$ & $(-2.49)$ & $(-4.04)$ & $(-3.12)$ \\
\hline \multirow[t]{2}{*}{ Economic risk } & $E R$ & 0.114 & 0.011 & -0.012 & 0.014 & 0.023 & 0.057 & 0.066 \\
\hline & & $(1.13)$ & $(0.16)$ & $(-0.32)$ & $(0.34)$ & $(0.46)$ & $(0.94)$ & $(0.97)$ \\
\hline \multirow[t]{2}{*}{ Financial risk } & $F R$ & $0.222 * * *$ & $0.209 * * *$ & $0.208 * * *$ & 0.001 & -0.008 & -0.023 & -0.015 \\
\hline & & $(2.61)$ & $(3.33)$ & $(3.88)$ & $(0.02)$ & $(-0.16)$ & $(-0.37)$ & $(-0.26)$ \\
\hline \multirow[t]{2}{*}{ Political risk } & $P R$ & 0.239 & 0.021 & 0.088 & -0.026 & -0.059 & $-0.311 * *$ & $-0.292 * *$ \\
\hline & & $(1.29)$ & $(0.15)$ & $(0.78)$ & $(-0.25)$ & $(-0.58)$ & $(-2.22)$ & $(-2.39)$ \\
\hline \multirow[t]{2}{*}{ Global bond market returns } & $G B R$ & $1.009 * * *$ & $1.172 * * *$ & $1.267 * * *$ & $1.299 * * *$ & $1.303 * * *$ & $1.213 * * *$ & $1.105^{* * *}$ \\
\hline & & $(12.61)$ & $(17.92)$ & $(21.85)$ & $(34.35)$ & $(49.28)$ & $(31.17)$ & $(20.81)$ \\
\hline \multirow[t]{2}{*}{ Global liquidity conditions } & $G L I Q$ & -0.001 & -0.012 & $-0.017 * *$ & -0.006 & -0.002 & $0.023 * *$ & $0.028 * *$ \\
\hline & & $(-0.04)$ & $(-1.08)$ & $(-2.22)$ & $(-0.87)$ & $(-0.34)$ & $(2.47)$ & $(2.49)$ \\
\hline \multirow[t]{2}{*}{ Global bond market uncertainty } & $G U$ & $-0.037 * *$ & $-0.021 * *$ & -0.002 & $-0.015^{*}$ & $-0.014 * *$ & -0.011 & -0.018 \\
\hline & & $(-2.57)$ & $(-2.09)$ & $(-0.29)$ & $(-1.96)$ & $(-2.33)$ & $(-1.44)$ & $(-1.60)$ \\
\hline \multirow[t]{2}{*}{ Global financial conditions } & $G F C$ & $-4.092 * * *$ & $-3.261 * * *$ & $-2.012 * * *$ & $-1.050 * * *$ & $-0.645 * *$ & $1.144 * *$ & $1.778 * * *$ \\
\hline & & $(-4.46)$ & $(-4.30)$ & $(-6.63)$ & $(-3.58)$ & $(-2.09)$ & $(2.46)$ & $(3.37)$ \\
\hline \multirow[t]{2}{*}{ Constant } & & $-24.695 * * *$ & $-16.352 * * *$ & $-4.702 *$ & 1.252 & $7.023 * * *$ & $17.527 * * *$ & $23.677 * * *$ \\
\hline & & $(-4.46)$ & $(-3.11)$ & $(-1.81)$ & $(0.82)$ & $(3.21)$ & $(4.37)$ & (3.69) \\
\hline Pseudo $\mathrm{R}^{2}$ & & 0.29 & 0.32 & 0.37 & 0.44 & 0.45 & 0.45 & 0.45 \\
\hline
\end{tabular}

This table presents the quantile regression estimates for developed markets according to the empirical model defined by Equation (1). Description of the variables is the same as in Table 3 . The numbers in parentheses are $\mathrm{t}-$-statistics, computed using the bootstrapped cluster standard errors. $*$, $* *, * * *$ denote statistical significance at the $10 \%, 5 \%$, and $1 \%$ levels, respectively. 
Table 6. Quantile regression results for emerging markets

\begin{tabular}{|c|c|c|c|c|c|c|c|c|}
\hline \multirow[b]{2}{*}{$\begin{array}{l}\text { Dependent variable: } \\
\text { government bond returns }\end{array}$} & \multirow[b]{2}{*}{ Variable abbreviation } & \multicolumn{7}{|c|}{ Quantile } \\
\hline & & 0.05 & 0.10 & 0.25 & 0.50 & 0.75 & 0.90 & 0.95 \\
\hline \multirow[t]{2}{*}{ Financial development } & $F D$ & $-0.032 *$ & $-0.017 *$ & 0.000 & 0.004 & 0.004 & $0.016 * *$ & $0.034 * * *$ \\
\hline & & $(-1.77)$ & $(-1.68)$ & $(-0.02)$ & $(0.84)$ & $(0.73)$ & $(2.05)$ & (3.03) \\
\hline \multirow[t]{2}{*}{ Inflation } & $I N F$ & 0.572 & 0.033 & 0.276 & 0.163 & $0.308 *$ & $0.542 * *$ & 0.510 \\
\hline & & (1.12) & $(0.08)$ & (1.04) & (1.19) & (1.69) & $(2.110)$ & $(1.06)$ \\
\hline \multirow[t]{2}{*}{ GDP growth } & $G D P$ & 0.015 & 0.010 & 0.010 & 0.011 & 0.018 & 0.032 & 0.026 \\
\hline & & $(0.44)$ & $(0.38)$ & $(0.48)$ & $(0.64)$ & $(0.87)$ & (1.13) & $(0.81)$ \\
\hline \multirow[t]{2}{*}{ Sovereign credit rating } & $C C R$ & $1.738 * * *$ & $0.976 * * *$ & $0.248^{*}$ & $-0.206 * *$ & $-0.599 * * *$ & $-1.201 * * *$ & $-1.792 * * *$ \\
\hline & & $(3.25)$ & $(3.17)$ & $(1.76)$ & $(-2.41)$ & $(-3.54)$ & $(-5.06)$ & $(-4.96)$ \\
\hline \multirow[t]{2}{*}{ Economic risk } & $E R$ & $0.186^{*}$ & -0.041 & -0.015 & 0.009 & -0.028 & -0.099 & -0.008 \\
\hline & & $(1.70)$ & $(-0.38)$ & $(-0.18)$ & $(0.18)$ & $(-0.54)$ & $(-0.97)$ & $(-0.07)$ \\
\hline \multirow[t]{2}{*}{ Financial risk } & $F R$ & 0.009 & 0.161 & 0.092 & $0.190 * *$ & $0.139 * *$ & $0.135 *$ & 0.019 \\
\hline & & $(0.06)$ & $(1.20)$ & $(1.37)$ & $(3.12)$ & $(2.00)$ & $(1.85)$ & $(0.17)$ \\
\hline \multirow[t]{2}{*}{ Political risk } & $P R$ & 0.399 & 0.305 & $0.252 * *$ & 0.070 & 0.044 & 0.0212 & -0.115 \\
\hline & & $(1.20)$ & $(1.21)$ & $(2.08)$ & $(0.71)$ & $(0.31)$ & $(0.08)$ & $(-0.31)$ \\
\hline \multirow[t]{2}{*}{ Global bond market returns } & $G B R$ & 0.209 & 0.185 & $0.302 * * *$ & $0.317 * * *$ & $0.326 * * *$ & $0.327 * * *$ & $0.294 * * *$ \\
\hline & & $(1.21)$ & $(1.61)$ & $(5.18)$ & $(5.73)$ & $(4.91)$ & $(4.34)$ & $(2.61)$ \\
\hline \multirow[t]{2}{*}{ Global liquidity conditions } & GLIQ & 0.012 & 0.021 & $0.023 * *$ & $0.022 * * *$ & $0.015 *$ & 0.017 & 0.011 \\
\hline & & $(0.55)$ & $(1.44)$ & $(2.38)$ & $(3.53)$ & $(1.83)$ & $(1.55)$ & $(0.75)$ \\
\hline \multirow[t]{2}{*}{ Global bond market uncertainty } & $G U$ & $-0.063 * *$ & $-0.069 * * *$ & $-0.044 * * *$ & $-0.041 * * *$ & $-0.039 * * *$ & $-0.026^{*}$ & -0.018 \\
\hline & & $(-2.50)$ & $(-5.66)$ & $(-4.12)$ & $(-3.75)$ & $(-3.08)$ & $(-1.92)$ & $(-0.93)$ \\
\hline \multirow[t]{2}{*}{ Global financial conditions } & $G F C$ & $-2.846^{*}$ & -0.576 & 0.026 & 0.312 & $0.818 * *$ & 0.831 & 1.170 \\
\hline & & $(-1.95)$ & $(-0.54)$ & $(0.05)$ & $(0.78)$ & $(2.02)$ & $(1.62)$ & $(1.58)$ \\
\hline \multirow[t]{2}{*}{ Constant } & & $-27.415 * * *$ & $-14.502 * * *$ & $-3.867 * *$ & $4.069 * * *$ & $11.285 * * *$ & $20.398 * * *$ & $28.468 * * *$ \\
\hline & & $(-3.77)$ & $(-3.41)$ & $(-2.17)$ & $(3.77)$ & $(5.56)$ & $(6.77)$ & $(5.99)$ \\
\hline Pseudo $\mathrm{R}^{2}$ & & 0.26 & 0.16 & 0.09 & 0.09 & 0.14 & 0.26 & 0.35 \\
\hline
\end{tabular}

This table presents the quantile regression estimates for emerging markets according to the empirical model defined by Equation (1). Description of the

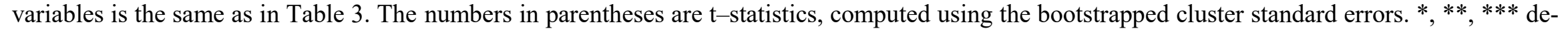
note statistical significance at the $10 \%, 5 \%$, and $1 \%$ levels, respectively. 
Table 7. Test of inter-quantile differences

\begin{tabular}{|c|c|c|c|c|c|c|c|}
\hline & \multirow[b]{2}{*}{ Variable abbreviation } & \multicolumn{2}{|c|}{ Full sample } & \multicolumn{2}{|c|}{ Developed markets } & \multicolumn{2}{|c|}{ Emerging markets } \\
\hline & & $\mathrm{q} 0.05=\mathrm{q} 0.50$ & $\mathrm{q} 0.95=\mathrm{q} 0.50$ & $\mathrm{q} 0.05=\mathrm{q} 0.50$ & $\mathrm{q} 0.95=\mathrm{q} 0.50$ & $\mathrm{q} 0.05=\mathrm{q} 0.50$ & $\mathrm{q} 0.95=\mathrm{q} 0.50$ \\
\hline Financial development & $F D$ & $\begin{array}{c}-0.02 * * * \\
(0.00)\end{array}$ & $\begin{array}{c}-0.01 * * \\
(0.00)\end{array}$ & $\begin{array}{l}-0.01 \\
(0.00)\end{array}$ & $\begin{array}{c}-0.02 * * \\
(0.00)\end{array}$ & $\begin{array}{c}-0.03 * * \\
(0.01)\end{array}$ & $\begin{array}{c}-0.03 * * * \\
(0.01)\end{array}$ \\
\hline Inflation & $I N F$ & $\begin{array}{c}-0.78 * * \\
(0.30)\end{array}$ & $\begin{array}{c}-0.79 * \\
(0.41)\end{array}$ & $\begin{array}{c}-1.64 * * * \\
(0.47)\end{array}$ & $\begin{array}{c}0.16 \\
(0.46)\end{array}$ & $\begin{array}{c}0.40 \\
(0.49)\end{array}$ & $\begin{array}{l}-0.34 \\
(0.46)\end{array}$ \\
\hline GDP growth & $G D P$ & $\begin{array}{c}-0.15 * * \\
(0.07)\end{array}$ & $\begin{array}{c}0.02 \\
(0.09)\end{array}$ & $\begin{array}{l}-0.03 \\
(0.14)\end{array}$ & $\begin{array}{l}-0.19 \\
(0.13)\end{array}$ & $\begin{array}{c}0.00 \\
(0.03)\end{array}$ & $\begin{array}{l}-0.01 \\
(0.03)\end{array}$ \\
\hline Sovereign credit rating & $C C R$ & $\begin{array}{c}0.79 * * * \\
(0.16)\end{array}$ & $\begin{array}{c}0.62 * * * \\
(0.14)\end{array}$ & $\begin{array}{c}1.07 * * * \\
(0.25)\end{array}$ & $\begin{array}{c}0.92 * * * \\
(0.30)\end{array}$ & $\begin{array}{c}1.94 * * * \\
(0.52)\end{array}$ & $\begin{array}{c}1.58 * * * \\
(0.36)\end{array}$ \\
\hline Economic risk & $E R$ & $\begin{array}{c}0.14 \\
(0.08)\end{array}$ & $\begin{array}{l}-0.11 \\
(0.08)\end{array}$ & $\begin{array}{c}0.09 \\
(0.10)\end{array}$ & $\begin{array}{l}-0.05 \\
(0.07)\end{array}$ & $\begin{array}{c}0.17 \\
(0.11)\end{array}$ & $\begin{array}{l}0.018 \\
(0.11)\end{array}$ \\
\hline Financial risk & $F R$ & $\begin{array}{c}0.01 \\
(0.08)\end{array}$ & $\begin{array}{c}0.08 \\
(0.06)\end{array}$ & $\begin{array}{c}0.22 * * \\
(0.08)\end{array}$ & $\begin{array}{c}0.01 \\
(0.06)\end{array}$ & $\begin{array}{l}-0.18 \\
(0.15)\end{array}$ & $\begin{array}{c}0.17 \\
(0.11)\end{array}$ \\
\hline Political risk & $P R$ & $\begin{array}{c}0.10 \\
(0.20)\end{array}$ & $\begin{array}{c}0.25 \\
(0.18)\end{array}$ & $\begin{array}{c}0.26 \\
(0.18)\end{array}$ & $\begin{array}{l}0.26^{*} \\
(0.14)\end{array}$ & $\begin{array}{c}0.32 \\
(0.32)\end{array}$ & $\begin{array}{c}0.18 \\
(0.34)\end{array}$ \\
\hline Global bond market returns & $G B R$ & $\begin{array}{l}-0.12 \\
(0.07)\end{array}$ & $\begin{array}{c}-0.10 * \\
(0.06)\end{array}$ & $\begin{array}{c}-0.29 * * * \\
(0.08)\end{array}$ & $\begin{array}{c}0.19 * * * \\
(0.05)\end{array}$ & $\begin{array}{l}-0.10 \\
(0.16)\end{array}$ & $\begin{array}{c}0.02 \\
(0.11)\end{array}$ \\
\hline Global liquidity conditions & $G L I Q$ & $\begin{array}{l}-0.01 \\
(0.01)\end{array}$ & $\begin{array}{l}-0.01 \\
(0.01)\end{array}$ & $\begin{array}{c}0.00 \\
(0.01)\end{array}$ & $\begin{array}{c}-0.03 * * * \\
(0.01)\end{array}$ & $\begin{array}{l}-0.00 \\
(0.02)\end{array}$ & $\begin{array}{c}0.01 \\
(0.01)\end{array}$ \\
\hline Global bond market uncertainty & $G U$ & $\begin{array}{l}-0.00 \\
(0.01)\end{array}$ & $\begin{array}{l}-0.01 \\
(0.01)\end{array}$ & $\begin{array}{l}-0.02 \\
(0.01)\end{array}$ & $\begin{array}{c}0.00 \\
(0.01)\end{array}$ & $\begin{array}{l}-0.02 \\
(0.02)\end{array}$ & $\begin{array}{l}-0.02 \\
(0.02)\end{array}$ \\
\hline Global financial conditions & $G F C$ & $\begin{array}{c}-4.27^{* * *} \\
(0.73)\end{array}$ & $\begin{array}{c}-2.49 * * * \\
(0.59)\end{array}$ & $\begin{array}{c}-3.04 * * * \\
(0.91)\end{array}$ & $\begin{array}{c}-2.82 * * * \\
(0.58)\end{array}$ & $\begin{array}{c}-3.15^{* *} \\
(1.35)\end{array}$ & $\begin{array}{l}-0.85 \\
(0.79)\end{array}$ \\
\hline
\end{tabular}

This table presents the test statistics for the null hypothesis of equal slopes for 0.05 and 0.50 quantiles (testing the equality of slopes in bad and normal market conditions); and 0.95 and 0.50 quantiles (testing the equality of slopes in good and normal market conditions). Description of the variables is the same as in Table 3. The test statistics and standard errors (in parentheses) are reported for the full sample and subsamples of developed and emerging markets. $* * *, * *$ denote statistical significance at the $10 \%, 5 \%$, and $1 \%$ levels, respectively. 


\section{Appendix A}

Mean of Bond returns (full sample)

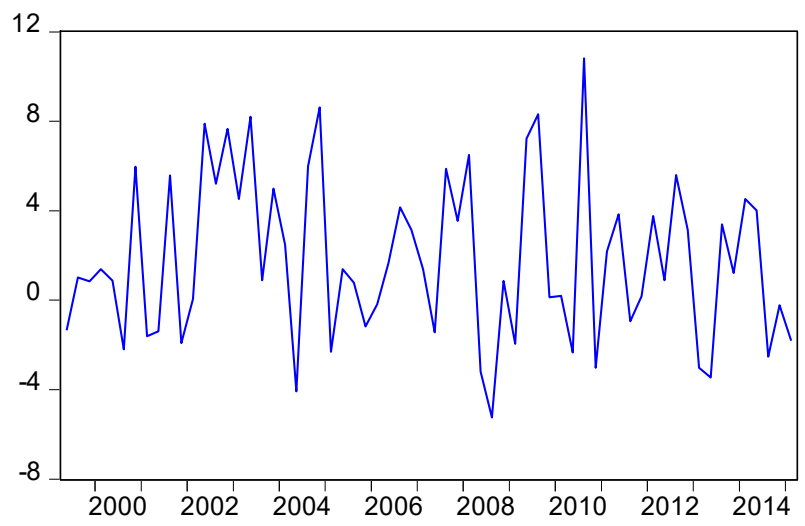

Mean ofBond returns (developed markets subsample)

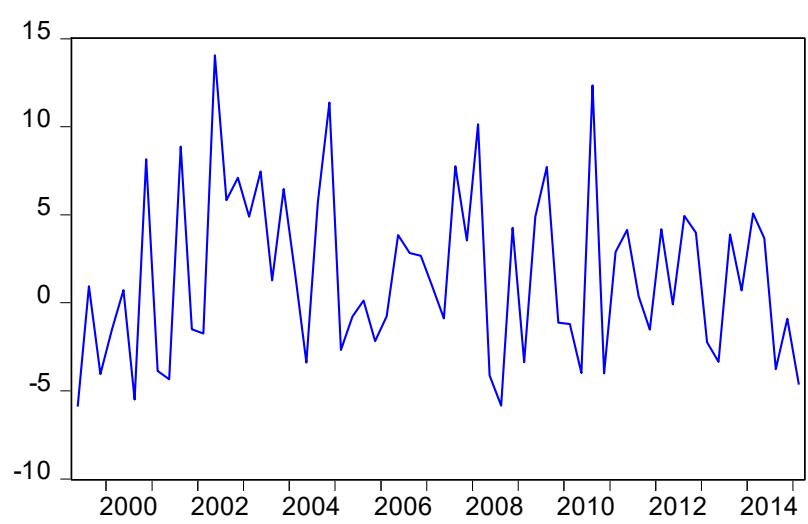

Mean ofBond returns (emerging markets subsample)

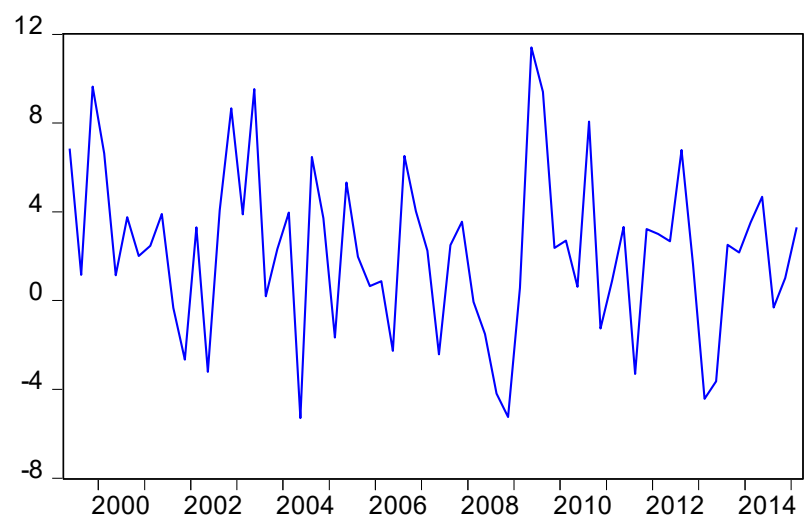

Mean of Financial development (full sample)

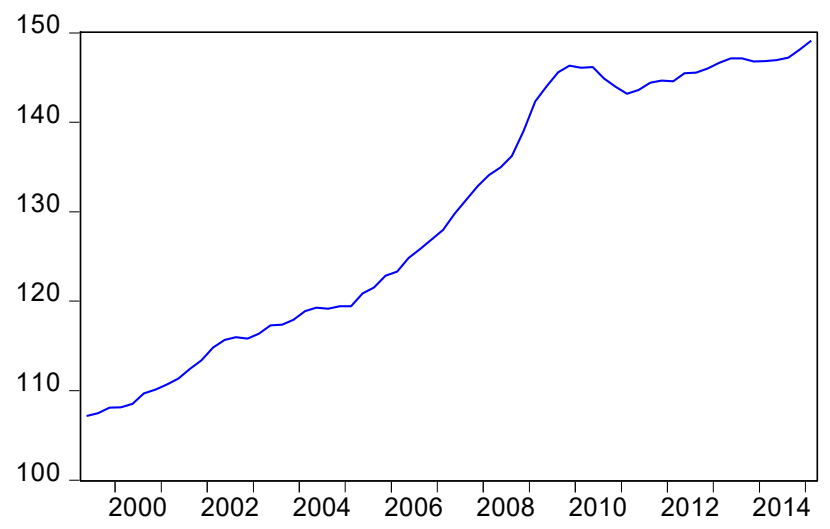

Mean ofFinancial development(developed markets subsample)

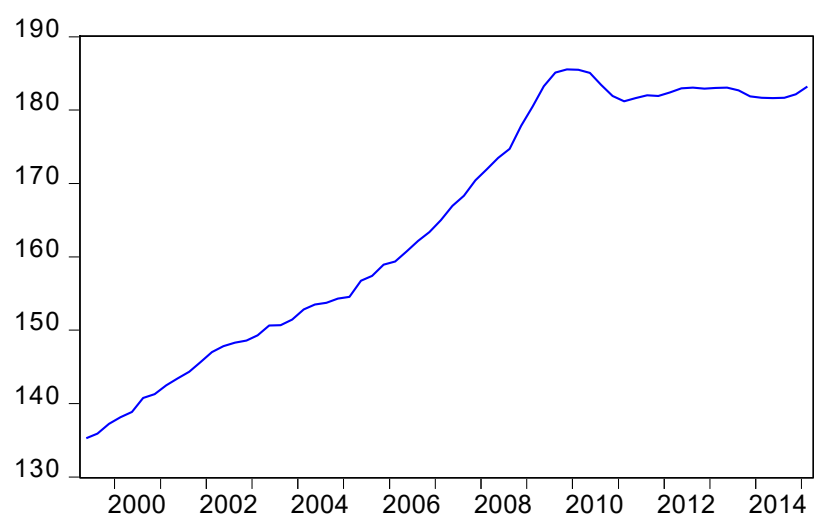

Mean ofFinancial development(emerging markets subsample)

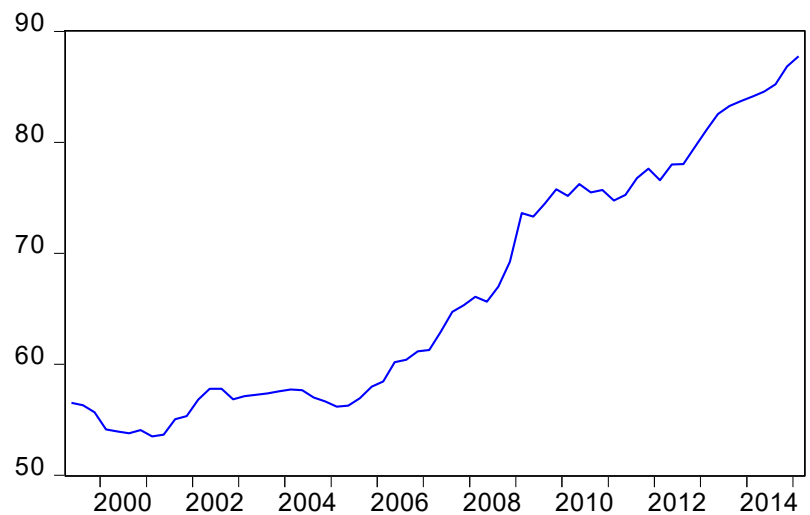

Figure A1. Evolution of the bond returns and financial development over time (full sample and subsamples of developed and emerging markets). 


\section{Appendix B}

Quantile Process Estimates (Full sample)
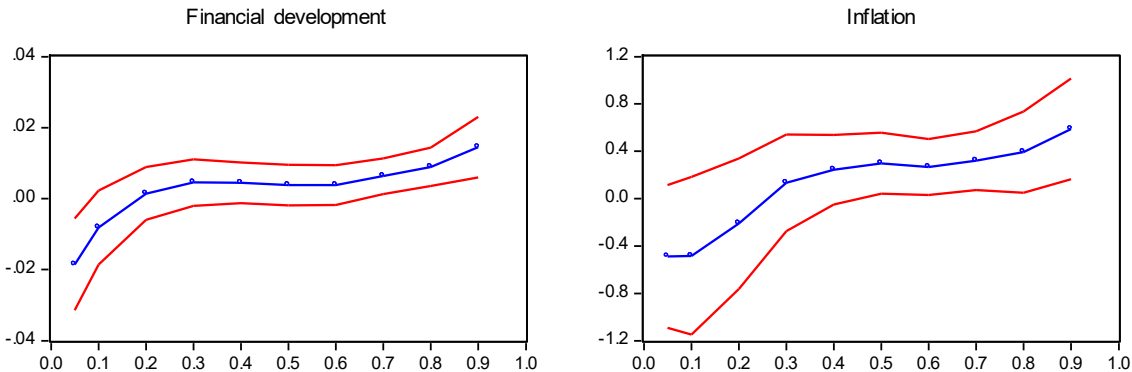

GDP growth
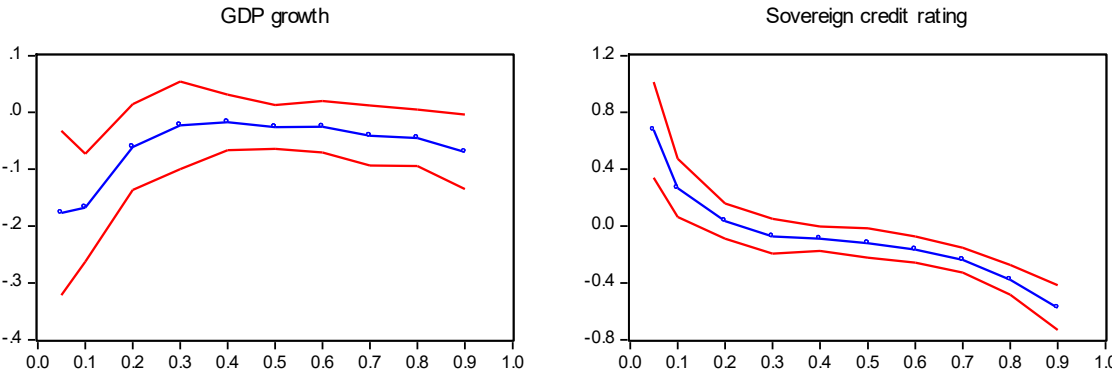

Quantile

Economic risk

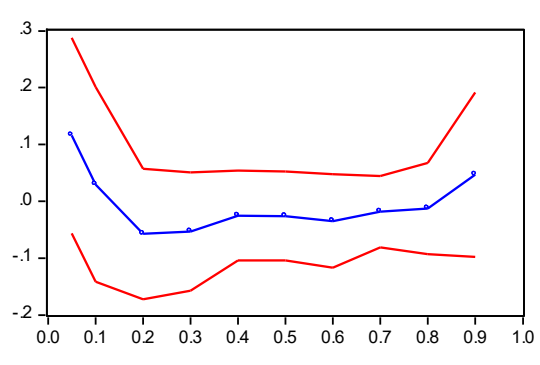

Financial risk

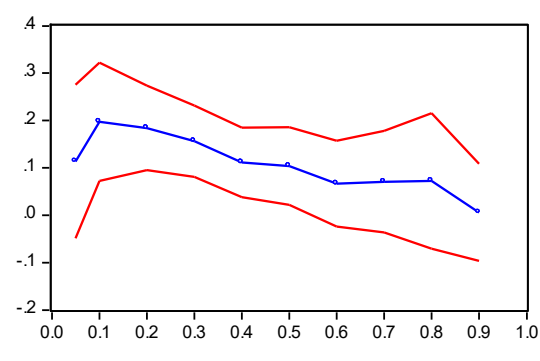

Quantile

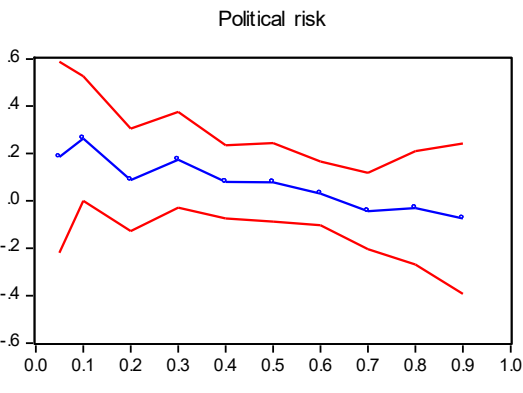

Quantile

Global financial conditions

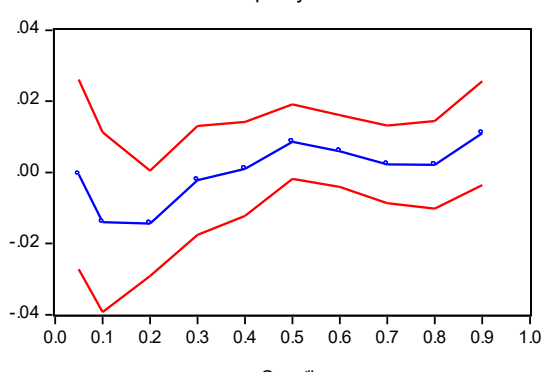

Global bond market uncertainty
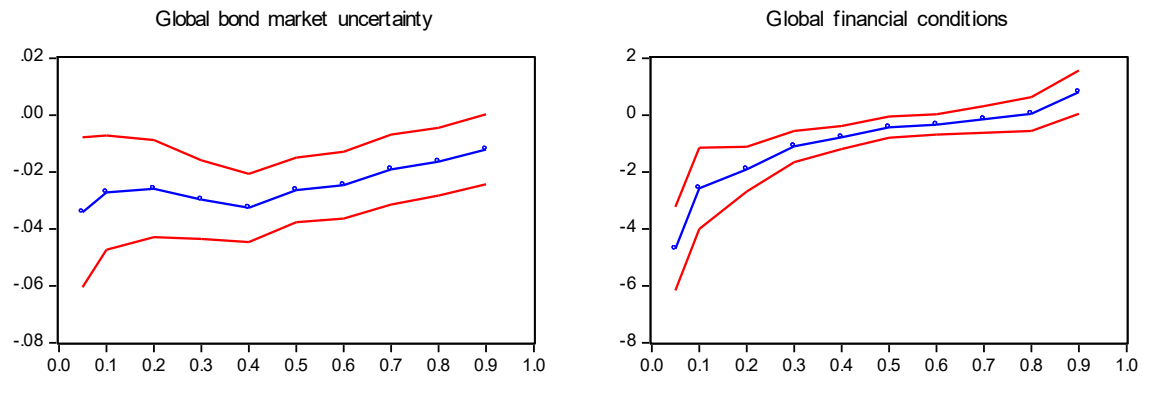

Global bond market returns

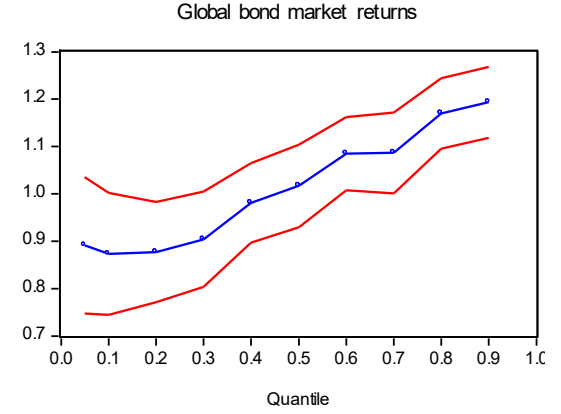

Constant

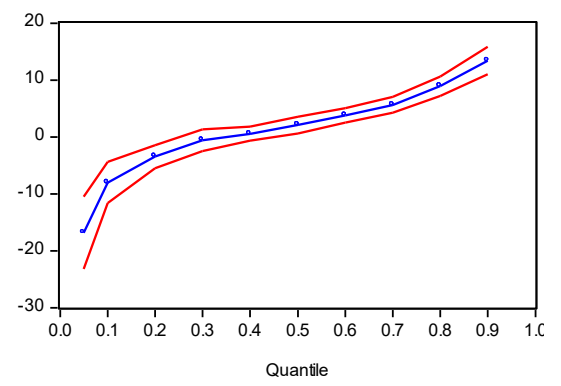

Figure B1. Quantile plot of the regression coefficients and $95 \%$ confidence interval for the full sample. 
Quantile Process Estimates (Developed markets subsample)

Financial development

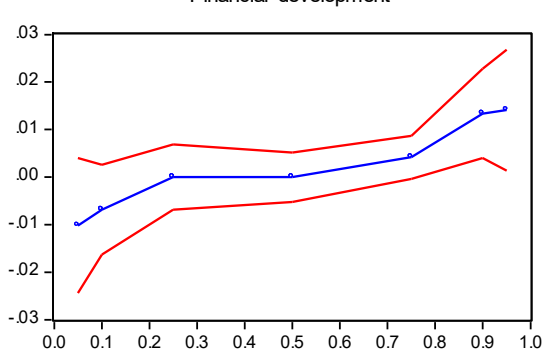

Quantile

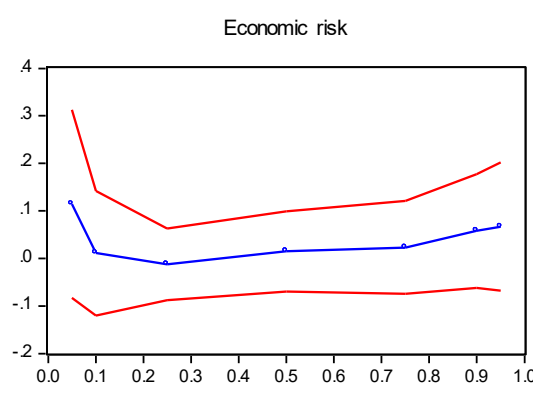

Quantile

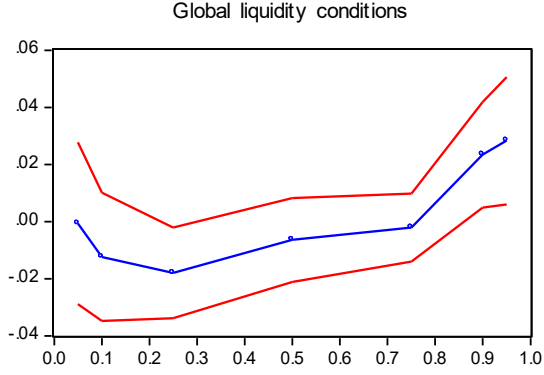

Quant
Inflation

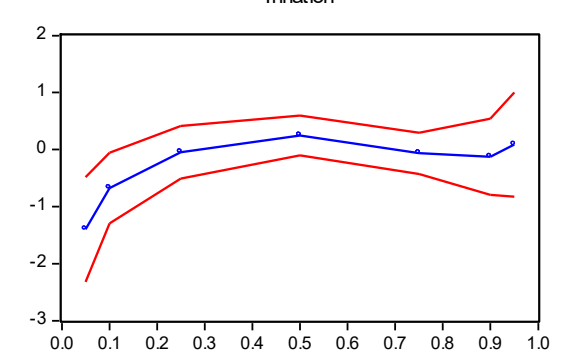

Quantile

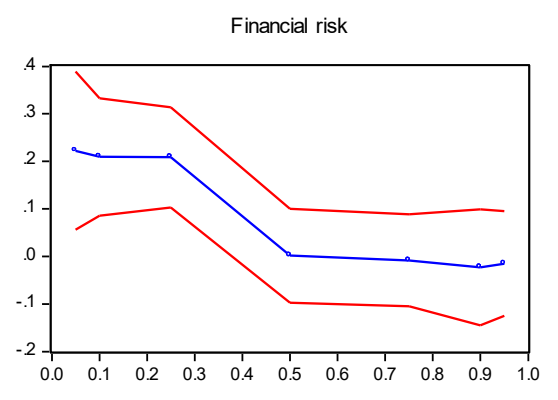

Quantile

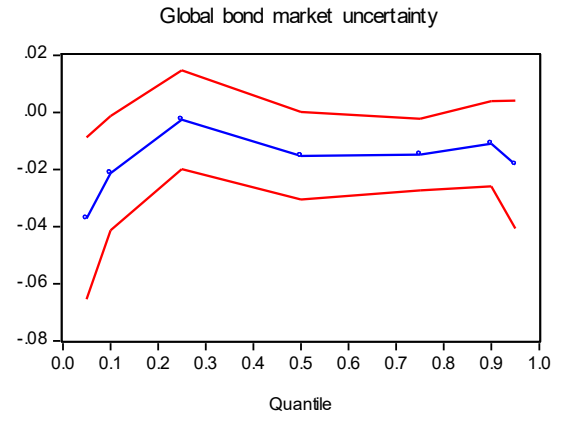

GDP growth
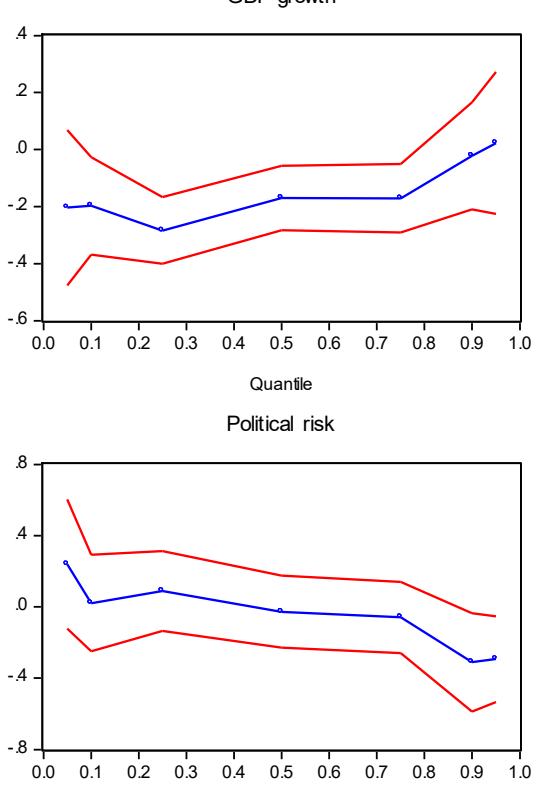

Quantile

Global financial conditions

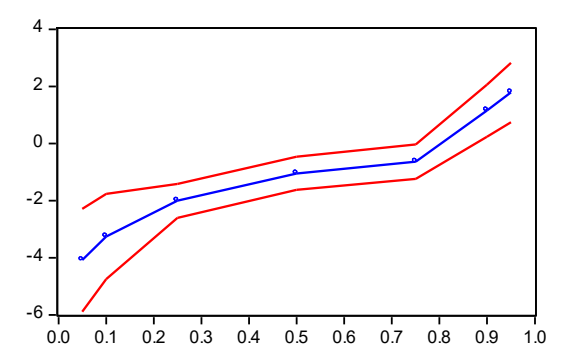

Quantile
Sovereign credit rating

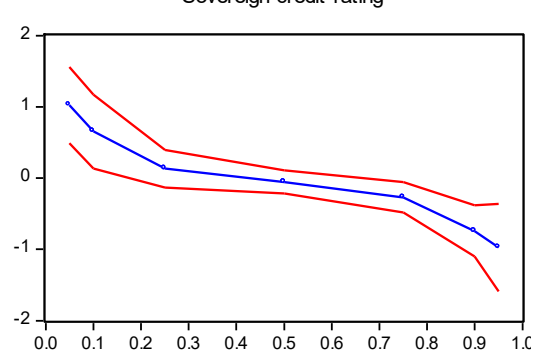

Quantile

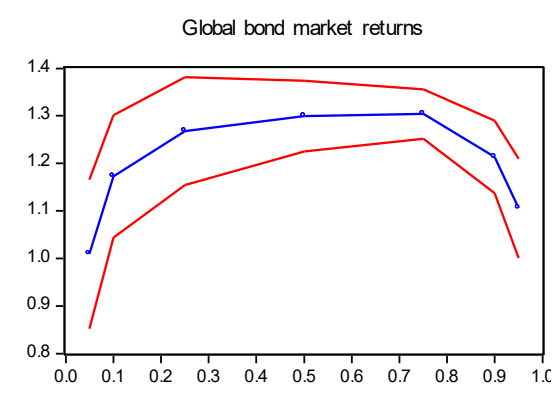

Quantile

Constant

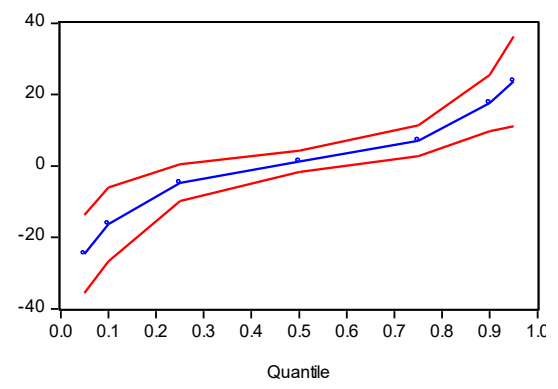

Figure B2. Quantile plot of the regression coefficients and 95\% confidence interval for developed markets subsample. 
Quantile Process Estimates (Emerging markets subsample)

Financial development

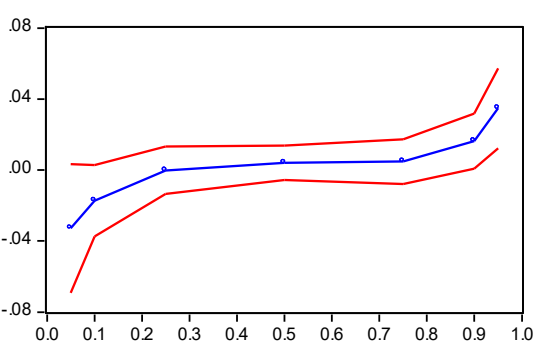

Quantile

Economic ris

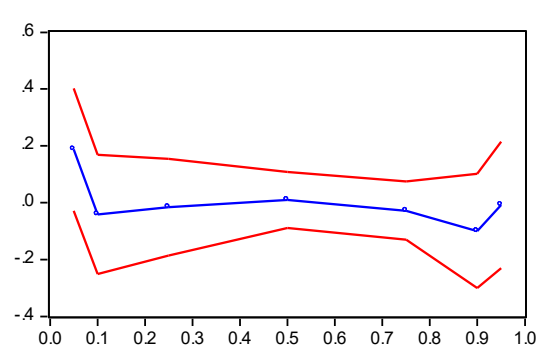

Quantile

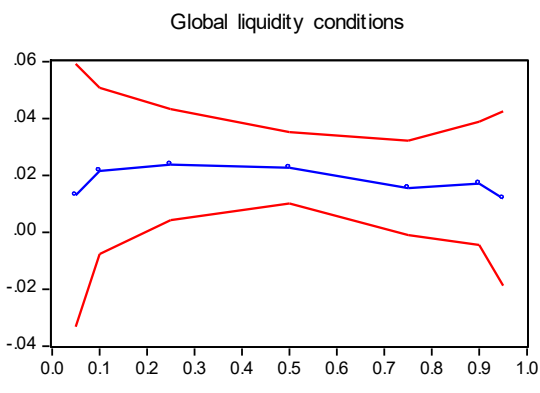

Quantle
Inflation

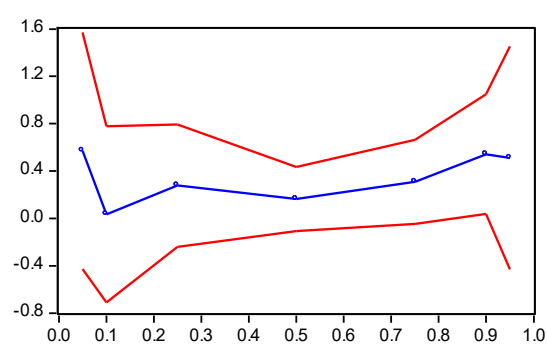

Quantile

Financial ris

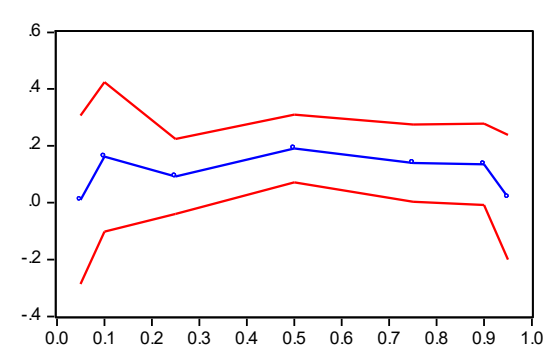

Quantile

Global bond market uncertainty

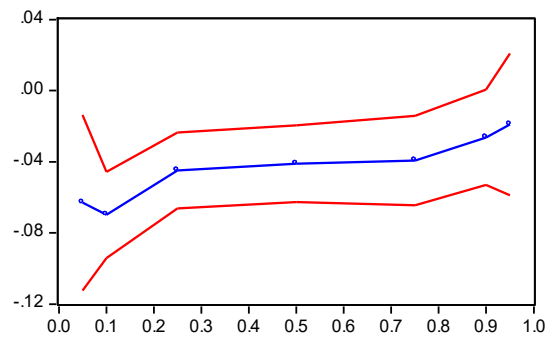

GDP growth

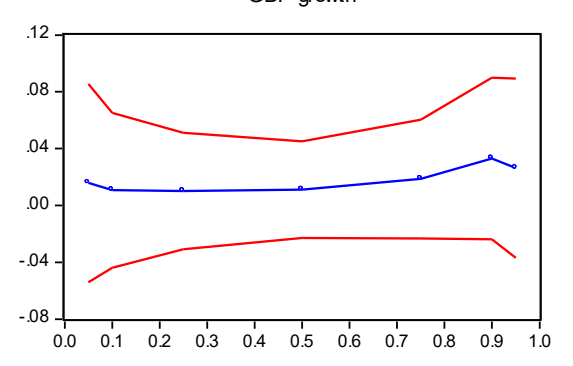

alitical risk

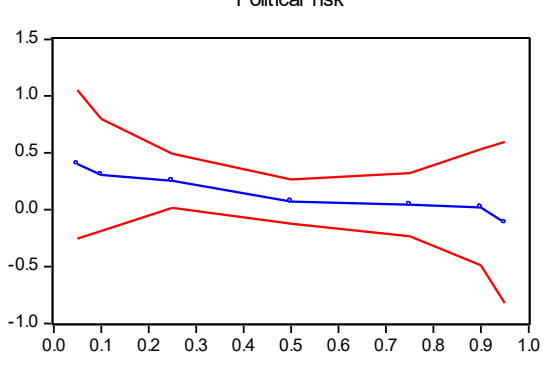

Quantile

Global financial conditions

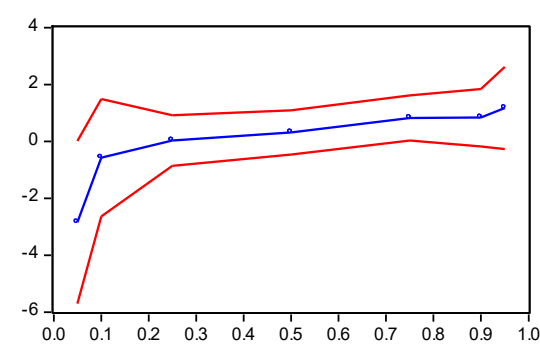

Quantile
Sovereign credit rating

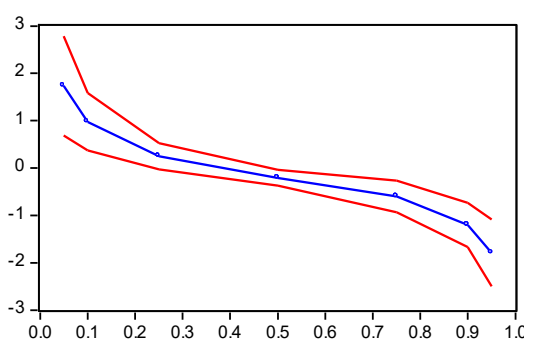
Quantile

Global bond market returns

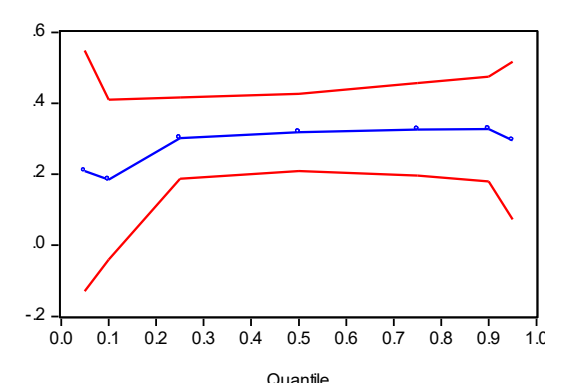

Constant

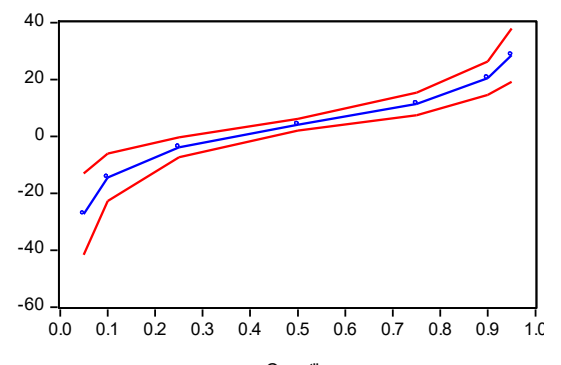

Quantile

Figure B3. Quantile plot of the regression coefficients and $95 \%$ confidence interval for emerging markets subsample. 